\title{
ARE THERE SIGNIFICANT DIFFERENCES BETWEEN MULTICULTURALISM AND INTERCULTURALISM?: \\ A STUDY OF THE INTEGRATION OF NEWCOMERS IN TORONTO AND MONTREAL
}

\author{
By
}

Lindsey Quan Oliveira

B.A. McMaster University, 2014

\author{
A Major Research Paper \\ Presented to Ryerson University \\ in partial fulfillment of the requirements for the degree of \\ Master of Arts \\ in the program of \\ Immigration and Settlement Studies
}

Toronto, Ontario, Canada, 2016

C) Lindsey Quan Oliveira 2016 


\section{AUTHOR'S DECLARATION FOR ELECTRONIC SUBMISSION OF A MAJOR RESEARCH PAPER (MRP)}

I hereby declare that I am the sole author of this Major Research Paper. This is a true copy of the MRP, including any required final revisions, as accepted by my examiners.

I authorize Ryerson University to lend this MRP to other institutions or individuals for the purpose of scholarly research.

I further authorize Ryerson University to reproduce this MRP by photocopying or by other means, in total or in part, at the request of other institutions or individuals for the purpose of scholarly research.

I understand that my MRP may be made electronically available to the public. 


\title{
ARE THERE SIGNIFICANT DIFFERENCES BETWEEN MULTICULTURALISM AND INTERCULTURALISM?: \\ A STUDY OF THE INTEGRATION OF NEWCOMERS IN TORONTO AND MONTREAL
}

\author{
Lindsey Quan Oliveira \\ Master of Arts, 2016 \\ Immigration of Settlement Studies \\ Ryerson University
}

\begin{abstract}
Immigrant integration is a prominent issue in Canada, in which one-fifth of the population is foreign-born. The Canadian government adopted an official policy of multiculturalism as a means of managing its growing diversity, proclaiming all minority cultures as equal. Meanwhile, Quebec has chosen to manage its diversity differently, adopting an unofficial policy of interculturalism, in an attempt to preserve its minority culture and language, and presenting some interesting questions about the integration of minorities in the province. This paper examines the political cultures of federal multiculturalism and Quebec's interculturalism, the ideals behind them, and the criticisms mounted against each. Using data from Statistics Canada, this study examines the impact of factors such as immigrant source countries, visible minority status, and religion on immigrants' economic and political outcomes. Based on the findings, it appears that immigrants in Montreal, and Quebec more widely, fare worse economically and politically than their counterparts in Toronto, and are falling well behind the Canadian-born population.
\end{abstract}

KEYWORDS: Toronto; Montreal; Multiculturalism; Interculturalism; Immigrant integration; Social inclusion of immigrants; Ethnic and religious minorities 


\section{ACKNOWLEDGEMENTS}

I would first like to thank all of the wonderful professors at Ryerson University who helped make the last year of my studies one of the most challenging, frustrating and rewarding experiences of my academic career. Thank you to my supervisor, Dr. Marco Fiola, who not only provided me with invaluable help while writing this MRP, but also taught me how to keep the process from overwhelming me. I would also like to acknowledge Dr. Kathleen Kellett as the second reader of this MRP, I am forever grateful for your help and suggestions. Thank you to my colleagues in this program for reminding me that late nights at the library are always better with friends.

Finally, I would like to thank my parents for supporting me throughout the ups and downs of my academic career, and always pushing me to achieve greater things, even when I pushed back. This degree belongs as much to you as it does to me. Thank you to the rest of my family, my friends, and to Gordie for providing me with the unwavering encouragement and coffee I needed to get through the process of researching and writing this MRP. I could not have done this without you all. Thank you. 


\section{TABLE OF CONTENTS}

$\begin{array}{ll}\text { Author's Declaration } & \text { ii }\end{array}$

$\begin{array}{lll}\text { Abstract } & \text { iii }\end{array}$

Acknowledgements

1. Introduction 1

2. Research Problem $\quad 8$

2.1. Research Question $\quad 10$

3. Conceptual Framework 11

4. Literature Review 20

4.1. The Policy of Multiculturalism in Canada: History \& Practice 21

4.1.1. Creation as a Policy 23

$\begin{array}{ll}\text { 4.1.2. Criticisms of Multiculturalism } & 27\end{array}$

4.1.3. Limits to the Practice of Multiculturalism? 31

4.2. The Policy of Interculturalism: How Quebec Got to Now 34

4.2.1. The Evolution of L'interculturalisme 34

4.2.2. Contemporary Interculturalism in Quebec 40

4.2.3. What is Reasonable Accommodation? The Bouchard-Taylor Report 46

5. The Composition and Outcomes of Immigrants in Toronto and Montreal 52

5.1. Country of Origin and Visible Minorities $\quad 54$

5.2. Language $\quad 57$

5.3. Religion $\quad 59$

5.4. Economic Outcomes: Employment and Income $\quad 62$

5.5. Political Outcomes: Voting and Civic Engagement 71

$\begin{array}{ll}\text { 6. Discussion and Conclusion } & 76\end{array}$

$\begin{array}{lr}\text { 7. Bibliography } & 81\end{array}$ 
Introduction

The Canadian state has managed to maintain a rather harmonious relationship with the hundreds of ethnic and minority communities living within its borders. Canada has managed to avoid any major clashes between immigrant groups themselves, between these groups and the native-born population, with perhaps the exception of some of Canada's indigenous populations, or between any of these communities and the state, with the exception of Quebec's longestablished separatist movement. A report on the economic and social outcomes of immigrants in Canada, conducted on behalf of Statistics Canada in 2008, posits that this balance is the result of Canada's inherently pluralistic nature. Since Confederation in 1867, Canada, unlike many other nations that were colonized and settled, has never been able to develop a single national identity. Leading up to Confederation, the English populations of modern Ontario, and the French populations of modern Quebec, represented Canada's two main founding peoples who possessed different languages, religions, cultures and histories. ${ }^{1}$ These differences were compounded by the fact that Canada was also home to numerous First Nations communities, and several growing immigrant groups from countries besides Britain and France, and increasingly from non-Western European countries, making it more difficult to produce that single identity. Since Confederation, Canada has grown to include hundreds of ethnic and religious minority groups from across the globe, each of which bring their own identity and culture to Canada. While Canada may not be the idyllic multicultural haven that it advertises to the world, its immigrants, descendants of immigrants, and indigenous populations live together in relative harmony.

\footnotetext{
1 Garnett Picot, Immigrant and Economic Social Outcomes in Canada: Research and Data Development at Statistics Canada, Statistics Canada, Research Paper, Catalogue no. 11F0019M — No. 319: 28.
} 
While all newcomers ${ }^{2}$ are free to settle in any province or territory, 91 percent of immigrants have clustered in one of Canada's 33 census metropolitan areas (CMAs) in 2011, many with large established ethnic communities. ${ }^{3}$ According to the National Household Survey (NHS), an overwhelming majority, about 85 percent, of immigrants in Canada have settled in Ontario, British Columbia and Quebec. ${ }^{4}$ The NHS defines an immigrant as a person who is, or has previously been, a landed immigrant/permanent resident, which includes refugees, but excludes non-permanent residents, persons with permits to work or study in Canada and refugee claimants. ${ }^{5}$ The country's three largest CMAs - Toronto, Vancouver and Montreal — accounted for 63 percent of Canada's immigrant population, while only constituting one-third, or 35 percent, of Canada's total population. ${ }^{6}$ Toronto continues to have the country's largest immigrant population, both in terms of gross population and proportion to the native-born population, accounting for 46 percent of the CMA's total population, while Montreal is home to the third largest share of the country's immigrants, representing 23 percent of the CMA's total population. ${ }^{7}$ While these two metropolitan areas operate under similarly high immigration levels and the same federal government, each practices differing newcomer integration strategies, at least in theory. While diversity management in Toronto falls under the domain of the official

\footnotetext{
${ }^{2}$ The terms 'immigrant' and 'newcomer' will be used interchangeably. Both terms refer to persons who were born outside of Canada, and have migrated from their country of birth to settle in Canada. This definition includes landed immigrants/permanent residents and refugees.

${ }^{3}$ National Household Survey, 2011, Immigration and Ethnocultural Diversity in Canada, Statistics Canada, Catalogue no. 99-010-X2011001, 2013: 10.

${ }^{4}$ Ibid., 9.

${ }^{5}$ Ibid., 4.

${ }^{6}$ Ibid., 10.

${ }^{7}$ Ibid., 10.
} 
federal policy of multiculturalism, Montreal, and Quebec more generally, has chosen to pursue an unofficial policy of interculturalism.

Canada's multicultural policy extends across the nation, and in cities like Toronto, this diversity is very evident. With 47 percent of Toronto's population identifying as a visible minority in 2011, Toronto is home to the largest number and share of both immigrants and visible minorities. ${ }^{8}$ Meanwhile, it is slightly different in Montreal, and Quebec more widely, as demonstrated by the recent public and political debates concerning the province's reasonable accommodation practices and proposed secularism charter bill. Given the distinct cultural and political history and ethnic identity of the majority of Quebec's citizens, the issue of whether immigrants, both new and old, experience integration and inclusion differently than in the rest of Canada is called into question. Quebecers ${ }^{9}$ represent a national minority — one of Canada's founding peoples — and see themselves as a shrinking minority within the Canadian state. According to the 2011 Canadian Election Study, a majority of Quebec residents, about 53 percent, believed that too many recent immigrants just do not want to fit into Canadian society, while 52 percent believed that recent immigrants should set aside their cultural backgrounds and blend into Canadian society. ${ }^{10}$ Immigrants, whether welcome or not, are said to have the potential to dilute the Quebec minority language, traditions, values and culture. ${ }^{11}$ In the last decade, this has led to increased friction between immigrant groups and Quebecers of French-

\footnotetext{
${ }^{8}$ National Household Survey, 2011, Immigration and Ethnocultural Diversity in Canada, 17.

${ }^{9}$ The term 'Quebecer' will be used throughout this paper to refer to French-speaking persons of French-Canadian origin living in Quebec.

${ }^{10}$ Institute for Social Research, 2013, Canadian Election Study, 2011 Panel.

${ }^{11}$ Gérard Bouchard, Interculturalism: A View From Quebec (Toronto: University of Toronto Press, 2015$), 11$.
} 
Canadian origin, as many consider the influx of newcomers to be a challenge to the Quebec way of life. ${ }^{12}$

The Canadian government adopted multiculturalism as an official policy in 1988, formally recognizing that all citizens are equal, ensuring that they can keep their identities, regardless of country of origin, while also encouraging integration. ${ }^{13}$ The Multiculturalism Act acknowledged that every citizen has an ethnic origin — which is defined as a cultural, national or racial origin - that each citizen's culture must be respected, and that cultural pluralism needs official support. ${ }^{14}$ Meanwhile, Quebec's unofficial policy of interculturalism outlines a slightly different relationship between immigrants and their host society. Newcomers are expected to respect Quebec's fundamental values, and in return the province must appreciate the contributions of immigrants. The policy of interculturalism attempts to find a balance between, on the one hand, ethnocultural diversity, and on the other, the preservation of Quebec's Frenchspeaking identity and history. ${ }^{15}$ While promoting equality of all citizens, interculturalism emphasizes the second of these elements, as it reflects the majority Quebecers' cultural insecurity as a minority group within Canada. ${ }^{16}$

The conditions of immigrant selection and integration in Quebec are particularly interesting for two reasons. The first is due to the province's prevailing national minority culture.

\footnotetext{
12 Gada Mahrouse, “Reasonable Accommodation' in Quebec: The Limits of Participation and Dialogue,” Race and Class 52 no.1 (2010): 86.

${ }^{13}$ Michael Adams, Unlikely Utopia: The Surprising Triumph of Canadian Multiculturalism (Toronto: Penguin Canada, 2008), 77.

${ }^{14}$ Richard J.F. Day, Multiculturalism and the History of Canadian Diversity (Toronto: University of Toronto Press, 2000), 189.

${ }^{15}$ Gérard Bouchard and Charles Taylor, "Building the Future: A Time for Reconciliation," Bibliothèque et Archives Nationales du Québec, 2008, 119.

16 Ibid., 119.
} 
Deep historic divides exist between Canada's English majority and Francophone minority, which provides the context for distinct experiences for many ethnic and religious minorities who settle in the province. Francophones represent a strong majority in Quebec, whereas in the rest of Canada they are a much smaller minority and often feel very defensive about the future of their language and culture. ${ }^{17}$ The second reason involves Quebec's distinct immigration and settlement policies. In 1978, the Couture-Cullen Agreement secured the Quebec government's right to set its own objectives concerning the volume and composition of immigrants to the province. While the federal government retained control over refugee selection, family reunification, and visas, the province was granted a dominant role in selecting permanent residents under the Economic Class. This power was extended in the 1991 Canada-Quebec Accord, giving Quebec exclusive rights to select its independent immigrants. ${ }^{18}$

The greatest effect of these agreements was in allowing Quebec to establish its own points system, differing from the federal approach, and placing a greater weight on Frenchlanguage skills to preserve French as the province's dominant language. As a result, the majority of immigrants to Quebec come from Haiti, France, and many countries in North Africa and the Middle East, where French is one of the official languages, or is spoken widely.

Over the past decade, Quebec's four main immigrant source countries have remained Algeria, Morocco, France and Haiti. ${ }^{19}$ Consequently, many recent immigrants to the province identify as

\footnotetext{
${ }^{17}$ Keith Banting and Stuart Soroka, "Minority Nationalism and Immigrant Integration in Canada," Nations and Nationalism 18 no.1 (2012): 158.

${ }^{18}$ Fiona Barker, "Learning to be a Majority: Negotiating Immigration, Integration and National Membership in Quebec," Political Science 62 no.1 (2010): 22-23.

${ }^{19}$ Ministère de l'Immigration, de la Diversité et de l'Inclusion, Portraits régionaux 2004-2013: Caractéristiques des immigrants établis au Québec et dans les régions en 2015, Direction de la Planification, de la Recherche et des Statistiques, June 2015, 11.
} 
visible and religious minorities. Based on projections by Statistics Canada, Montreal's visible minority population is expected to double by 2031 , while the number of persons in the CMA belonging to a Christian religion is expected to fall by 12 percent. ${ }^{20}$ Tensions between immigrant communities and the Francophone majority have intensified in the last decade, culminating in several political and public debates about the integration, or lack thereof, of ethnic and religious minorities. ${ }^{21}$

In 2007, the small rural town of Hérouxville, Quebec passed a series of municipal Standards for new immigrants, which promoted gender equality, democratic values, and integration into the host society, and banned female circumcision, stoning, and smelly food..$^{22}$ Following intense public debate, both in favour of the code and against, the provincial government established the Consultation Commission on Accommodation Practices Related to Cultural Differences, also known as the Bouchard-Taylor Commission after its two co-chairs. The purpose of this Commission was to conduct a public inquiry into the scope and limits of reasonable accommodation, and provide recommendations to the government to "ensure that accommodation practices conform to Québec's values as a pluralistic, democratic, egalitarian society”. ${ }^{23}$ The final report, published in early 2008, concluded that Quebec did not have an identity problem, and recommended, among other things, that the Quebec government enshrine interculturalism in an official declaration, as a means of diminishing stereotypes and fostering

\footnotetext{
${ }^{20}$ Éric Caron Malenfant, André Lebel and Laurent Martel, Projections of the Diversity of the Canadian Population, 2006-2031, Statistics Canada, Catalogue no. 91-551-X, March 2010, 33.

${ }^{21}$ Bouchard and Taylor, "Building the Future: A Time for Reconciliation," 50.

${ }^{22}$ Mahrouse, “"Reasonable Accommodation'," 86; Daiva Stasiulis, "Worrier Nation: Quebec's Value Codes for Immigrants," Politikon 40 no.1 (2013): 203.

${ }^{23}$ Bouchard and Taylor, "Building the Future: A Time for Reconciliation," 17.
} 
participation in, and integration into, Quebec society. ${ }^{24}$ While the government has yet to implement this recommendation, the ideals and practices of interculturalism are still very present in Quebec. ${ }^{25}$

An important aspect of interculturalism is the idea of a secular society. The Quebec government became further involved with the question of accommodation and social inclusion when the minority Parti Québécois (PQ) government introduced the controversial Quebec Charter of Values, Bill 60, in 2013. The official title of the bill was: "Charter affirming the values of State secularism and religious neutrality and of equality between women and men, and providing a framework for accommodation requests". ${ }^{26}$ In addition to proposing constraints on newcomers' citizenship rights by requiring proof of French proficiency and knowledge of Quebec culture, the Charter proposed a measure of secularism to restrict "personnel members of public bodies" from expressing religious beliefs, as well as wearing "conspicuous religious symbols" which would overtly indicate a religious affiliation. ${ }^{27}$ This would restrict the wearing of hijabs, kippas, turbans, or conspicuous religious jewelry, like crucifixes, for every public servant in the province. These restrictions would extend to municipal personnel, teachers, daycare workers, police officers, judges, prosecutors and physicians, dentists and midwives who practice in a centre operated by a public health or social services institution, for example. ${ }^{28}$

\footnotetext{
${ }^{24}$ Bouchard and Taylor, "Building the Future: A Time for Reconciliation,” 269.

${ }^{25}$ Raffaele Iacovino, "Contextualizing the Quebec Charter of Values: Belonging Without Citizenship in Quebec," Canadian Ethnic Studies 47 no.1 (2015): 45.

${ }^{26}$ Iacovino, "Contextualizing the Quebec Charter of Values," 42.

${ }^{27}$ Ibid., 51-52.

${ }^{28}$ Bill 60, Charter affirming the values of State secularism and religious neutrality and of equality between women and men, and providing a framework for accommodation requests, 1st session, 40th legislature, 2013. http:// www.assnat.qc.ca/en/travaux-parlementaires/projets-loi/projet-loi-60-40-1.html, 17-18.
} 
Although the bill died on the table following the defeat of the PQ the next year, the proposed Charter highlights the conflicting ideologies of some Quebecers belonging to the dominant Francophone culture and the many minority cultures and religions within Quebec.

\section{$\underline{\text { Research Problem }}$}

Quebec's informal policy of interculturalism, distinct from Canada's multiculturalism, has been gradually introduced by Quebec's government as a means of remedying friction between its various ethnic communities, while still preserving Quebec's culture. Interculturalism has not been enshrined as the province's official newcomer integration policy in the same way that multiculturalism has been in the rest of Canada, although Quebec's government has increasingly described interculturalism as the ideal model, principle, and vision for which Quebec must strive. ${ }^{29}$ While supporters of interculturalism argue that this policy allows for the successful integration of all citizens through an emphasis on communal values and the reciprocal relationship between the Quebec majority and other cultural communities, its critics claim that it promotes discrimination by placing the culture and language of immigrants below that of the Quebec majority. These critics assert that interculturalism reproduces a social and economic hierarchy that prioritizes and favours Quebec culture, in which immigrants, particularly visible and religious minorities, are at the bottom.

It is easy to claim that, as a result of interculturalism, visible and religious minorities experience greater prejudice or exclusion in Quebec than those living under multiculturalism elsewhere in Canada. However, the rest of Canada is not immune to prejudice; its 2015 federal

\footnotetext{
${ }^{29}$ An Intercultural, Plural and Inclusive Québec, Ministère de l'Immigration, de la Diversité et de l'Inclusion,
} Consultation Paper, 2015: 1-2. 
elections were proof of this. As we will see, the political and public debates surrounding the Zero Tolerance for Barbaric Cultural Practices Act, Canada's responsibility concerning Syrian refugees, and a Muslim woman's right to wear her niqab during her citizenship ceremony seemed to dominate all other federal issues. Based on much of the rhetoric perpetuated by some within the Conservative Party, and some of its supporters, it appeared as if the notion of "Canadian values" was under attack, and many Canadians supported these laws and restrictions. This mentality challenged the idea that Canadian multiculturalism is an already achieved ideal, demonstrating that prejudice is both present and deep-rooted among some Canadians.

Ultimately, the Conservative party was defeated by the Liberals. During his victory speech, Justin Trudeau claimed that "we beat negative, divisive politics with a positive vision that brings Canadians together". ${ }^{30}$ While the new Liberal government appears to be making a greater effort to emphasize that Canada is an inclusive and successful multicultural society, the election period revealed some of the negative perceptions held by some Canadians about immigrant groups and their cultural practices, Muslims in particular. These perceptions follow the rising trends of Islamophobia, and a general anti-immigrant sentiment, in other Western immigrant-receiving nations following 9/11, such as the United States and the United Kingdom. ${ }^{31}$ The debates and opinions expressed during the federal election period were reflective of the aforementioned debates in Quebec, despite the differing immigration integration policies of Canada and Quebec.

\footnotetext{
${ }^{30}$ Andy Blatchford, "Justin Trudeau in victory speech: 'We beat fear with hope, we beat cynicism with hard work'," National Post, October 20, 2015, accessed April 9, 2016, http://news.nationalpost.com/news/canada/canadianpolitics/justin-trudeau-in-victory-speech-we-beat-fear-with-hope-we-beat-cynicism-with-hard-work.

${ }^{31}$ Augie Fleras, Racisms in a Multicultural Canada: Paradoxes, Politics and Resistance (Waterloo: Wilfred Laurier University Press, 2014), 104-105.
} 
Under multiculturalism, it appears that Canada is not immune to the same prejudices displayed by the residents of Hérouxville, many of the citizens who submitted deputations to the Bouchard-Taylor Commission, and the Members of the National Assembly who supported the Quebec Charter of Values. While theoretically different in its approach to the selection and integration of newcomers, it does not appear that multiculturalism and interculturalism differ greatly in practice. It is this phenomenon that I intend to explore throughout this paper.

\section{Research Question}

I am interested in examining the practical differences between Quebec and the rest of Canada's immigrant integration policies. While both policies maintain the equality and dignity of all cultures, identities and religions, the experience of immigration and integration under the two policies appear to be slightly different. I would like to examine why and how the Quebec government decided to establish the Bouchard-Taylor Commission and propose the Quebec Charter of Values, while the Canadian government has not made similar strides to study or restrict the practices of ethnic and religious minorities within the country, at least in the last decade. I would also like to examine whether these measures have impacted the ways in which new and established ${ }^{32}$ immigrants experience integration in Quebec, under its informal policy of interculturalism, compared to the experiences of immigrants in the rest of Canada, under the official policy of multiculturalism.

\footnotetext{
32 For the purpose of this paper, 'new immigrants' will refer to permanent residents who have lived in Canada for four years or less, while 'established immigrants' will refer to permanent residents who have lived in Canada for five years or more.
} 
In order to reasonably examine this issue, I will narrow my scope to a population of two comparatively similar samples: the immigrant populations of the Toronto and Montreal CMAs. I will also identify and discuss factors which may affect the integration of newcomers, such as their country of origin, language, and religion, as well as the outcomes of these factors, such as employment, income and civic participation. Therefore, my research question is:

How do the economic, social, and political outcomes of immigrants living in Toronto differ from immigrants in Montreal?

My sub-questions are:

How do the policies of multiculturalism and interculturalism affect these outcomes, if at all? Can the policies of multiculturalism and interculturalism be linked to these differences?

It is evident that I cannot definitively conclude whether multiculturalism or interculturalism fosters a greater acceptance of, or sense of belonging among, minorities, but I hope that my study may add to the slowly growing body of academic literature that is working towards a better social inclusion model for governments across Canada.

\section{$\underline{\text { Conceptual Framework }}$}

In order to address these questions, I must first discuss the theoretical lens through which I will examine the issue of immigrant integration. I will use the conceptual framework of social inclusion and exclusion, which will provide the base from which I will build this study. Social inclusion is an important aspect of immigrant integration, and is particularly relevant in my 
examination of ethnic and religious minorities' economic and social outcomes, as well as the anti-immigrant sentiment across Canada, including Quebec. This theoretical framework provides direction for the study and also reflects my own position on the problem.

The concept of social inclusion is inevitably linked with social exclusion, and although both have existed for as long as modern society itself, the two concepts have only gained academic and political recognition in the last few decades. Social inclusion, as a concept, began in the 1970s in France to explain the growing economic gap between groups in society, and in an attempt to better integrate those citizens who were falling into poverty. The concept started to gain credibility throughout Europe as a guide for many nations' growing social security systems. ${ }^{33}$ Since then, academics and politicians alike have expanded the concept to include the cultural and political elements that act as barriers to citizens' abilities to fully participate in society. 34

There is relatively little academic research available which uses the discourse of 'social inclusion' exactly, particularly in relation to immigration and minority populations, though this body of literature is growing in Canada. The majority of these publications and studies examine social integration or social cohesion as a measurement of immigrants' sense of belonging and attachment to Canada. This includes economic status, involvement in the labour market, political and civic engagement, experiences of discrimination, length of residence, and visible minority status. Meanwhile, in its relation to immigration integration, social inclusion is more broadly defined in terms of belonging, acceptance, and recognition. Social inclusion may only be

\footnotetext{
${ }^{33}$ Ratna Omidvar and Ted Richmond, "Immigrant Settlement and Social Inclusion in Canada," in Social Inclusion: Canadian Perspectives, ed. Ted Richmond and Anver Saloojee (Toronto: Laidlaw Foundation, 2005), 166-167.

${ }^{34}$ In the Margins, Part II: Reducing Barriers to Social Inclusion and Social Cohesion, Report of the Standing Senate Committee on Social Affairs, Science and Technology, June 2013: 6.
} 
achieved when immigrants are able to fully and equally participate in the economic, social, cultural and political realms of their new country. ${ }^{35}$

The difficulty in both defining social inclusion and actually carrying it out lies in the characteristics and qualities of the individual society in which an immigrant, or group of immigrants, desires to be included. In the case of Canada, including Quebec, the federal government has numerous laws and policies in place, including multiculturalism, to ensure that its immigrants, both recent and established, feel welcomed and included. Much of the existing literature cites Statistics Canada's Ethnic Diversity Study, conducted in 2002, for its distinctive investigation of relationships between ethnic groups, and within them. More recently, the federal government released its report In the Margins, Part II: Reducing Barriers to Social Inclusion and Social Cohesion, a national study examining the social inclusion and cohesion among Canadian citizens, with a large chapter devoted to the experiences of recent immigrants to Canada. The report recognizes the increasing diversity of immigrant groups over the past several decades, and the need for a corresponding increase in services to these communities to ensure their successful integration and engagement with Canadian society. ${ }^{36}$ Recent waves of immigrants have not fared as well economically as previous waves, mostly due to their increasing unfamiliarity with either of Canada's official languages and Canada's cultural norms. These factors, among others, increase the risks of economic and social exclusion of immigrants. ${ }^{37}$

Social exclusion is more broadly discussed in terms of poverty, unemployment, and barriers to social and political institutions, while discussions about inclusion focus on access and

\footnotetext{
${ }^{35}$ Omidvar and Richmond, "Immigrant Settlement," 155.

${ }^{36}$ In the Margins, 25.

${ }^{37}$ Ibid., 21.
} 
relative success with economic, social and political institutions. ${ }^{38}$ Economic inclusion is an important aspect of social inclusion, as exclusion in the labour market is correlated with lower wages, residential and employment segregation, and low political participation. Rising trends of poverty among immigrant families in Canada have a significant impact on immigrants' access to these institutions. High unemployment rates among immigrants, particularly recent immigrants, as we will see, create a series of repercussions. ${ }^{39}$ Immigrants are increasingly falling into the cycle of poverty, which in turn becomes a generational issue. It is much more likely that the children of immigrants, particularly racialized immigrants, will also live in poverty later in life, increasing feelings of alienation and limiting their ability to participate fully in society. ${ }^{40}$ Young people become disaffected with the school system, seeing that their older siblings and parents are unable to translate their skills and education into meaningful employment. This disaffection has serious consequences, both in terms of education and increased encounters with the criminal justice system. ${ }^{41}$

Ratna Omidvar and Ted Richmond argue that this downturn is due to the increase of immigrants arriving from non-European countries, and consequently, as visible minorities. Visible minorities are much more likely to live in low-income situations than non-visible minorities, especially women. Based on data from 2011, the prevalence of low income was 13 percent among non-visible minorities, compared with 19 percent of Canadian-born visible

\footnotetext{
${ }^{38}$ Robert Oxoby, "Understanding Social Inclusion, Social Cohesion, and Social Capital," International Journal of Social Economics 36 no.12 (2009): 1134.

${ }^{39}$ Omidvar and Richmond, "Immigrant Settlement", 168.

${ }^{40}$ Ibid., 164-165.

${ }^{41}$ Caroline Andrew and David Doloreux, "Economic Development, Social Inclusion and Urban Governance: The Case of the City-Region of Ottawa in Canada," International Journal of Urban and Regional Research 36, no.6 (November 2012): 1301.
} 
minorities, and 22 percent among visible minority immigrants. ${ }^{42}$ Additionally, immigrants to Canada from Africa, the Middle East, and Asia earned on average of $\$ 24,000$ less than immigrants from the United States and Europe. ${ }^{43}$ For Omidvar and Richmond, this is due to Canada's changing employment market. In recent years, immigrants have moved away from jobs in manufacturing and construction, which are rapidly being replaced by the service sector, to jobs in retail, hospitals and classrooms. This corresponds with Canada's transformation from a manufacturing-based economy to a largely service-based one, which tends to relegate immigrants, especially visible minority immigrants, into lower-wage and lower-skill services. ${ }^{44}$ Racial minorities, and in particular recent immigrants, are experiencing reduced success in the labour market, despite the fact that immigrant education and English-proficiency levels are at an all-time high. These downward trends in employment have resulted in an increase of poverty rates and a decrease in the standard of living of many recent immigrants. ${ }^{45}$ Omidvar and Richmond assert that all levels of government must engage with settlement agencies, mainstream institutions, employers and private foundations to address the exclusion experienced by newcomers, particularly visible minorities, through the creation of fair and transparent policies. They argue that these policies must recognize the potential of the economic contributions of

\footnotetext{
42 Tamara Hudon, "Visible Minority Women," Women in Canada: A Gender Based Statistical Report, Statistics Canada, Catalogue no. 89-503-X (2016): 31.

${ }^{43}$ Statistics Canada. Table 054-0002 - Income of immigrants, by world area, sex, immigrant admission category, education qualifications, knowledge of official languages, and landing year for tax year 2013, annual, CANSIM, accessed July 5, 2016.

${ }^{44}$ Omidvar and Richmond, "Immigrant Settlement", 157-158.

45 Jeffrey G. Reitz and Rupa Banerjee, "Racial Inequality and Social Integration," in Multiculturalism and Social Cohesion: Potentials and Challenges of Diversity, ed. Jeffrey G. Reitz (London: Springer, 2009), 123.
} 
immigrants and refugees, and must appropriately utilize their foreign-based experience, skill and education. ${ }^{46}$

A policy of this significance could play a key role in confronting the contradiction inherent in the immigrant selection process. When immigrants are denied access to the labour market based on their foreign credentials, when those same credentials helped them to gain citizenship in Canada, they are more likely to be relegated to lower paying jobs, inconsistent with their level of skill and education. Immigrants from many countries in Asia, Africa and South America tend to be disadvantaged due to a lack of credentials recognized by Canadian employers, combined with a lack of Canadian work experience and varying proficiencies in English. Even immigrants with considerable experience and education may discover that their certifications and references do not match the standards required by many Canadian employers. ${ }^{47}$ This means that these immigrants, who already face marginalization due to their visible minority status, face even further exclusion from the Canadian labour market, housing market and educational institutions.

Based on the existing literature, it is undeniable that the concepts of social inclusion and exclusion are significantly intertwined with ideas about equality and economic status. Jeffrey G. Reitz and Rupa Banerjee explore the ways in which inequalities foster a fragmented and socially exclusive society. First, racial bias or discrimination undermines the sense of fairness and inclusion felt by the marginalized, which breeds resentment and alienation. Second, those who do not feel connected to society are less likely to invest in it, whether that be the investment of

\footnotetext{
${ }^{46}$ Reitz and Banerjee, "Racial Inequality,” 171.

${ }^{47}$ In the Margins, 41.
} 
their time or their money. Third, individuals suffering from economic disadvantage and poverty are more likely to focus their energy on survival, rather than participation in the community. Fourth, as economic advancement is one of the main motives of immigration, failure is likely to have a significant impact on how newcomers interact with their new societies. Finally, employment success will help to break down barriers between culturally distinct minorities and their new communities. ${ }^{48}$

Many scholars argue in favour of increased efforts by economic and political institutions to promote social inclusion. Robert Oxoby argues that social exclusion is not only detrimental to the individuals experiencing exclusion, in the form of discrimination and poverty, but it is also detrimental to the nation's economy. Economic exclusion, he claims, drives ghettoization, and widens the divides between social classes. In order to develop further inclusion among society's most vulnerable, Oxoby suggests that political institutions must promote the right to political participation. When citizens feel that their voice and opinions matter in the shaping of their economy and policies, democratization usually follows and is positively correlated with economic development. ${ }^{49}$ Similarly, Howard Duncan argues that an increase in social inclusion naturally leads to an increase in social capital. This linear correlation, he contends, not only benefits the immigrants being included, but also the includees, as a more socially cohesive society is a more prosperous society. When immigrants are included in societies' workings and decision-making processes, that society may thrive and take advantage of all the capital, both social and economic, that its citizens have to offer. ${ }^{50}$

\footnotetext{
${ }^{48}$ Reitz and Banerjee, "Racial Inequality," 123-124.

49 Oxoby, “Understanding Social Inclusion,” 1145.

${ }^{50}$ Duncan Howard, “Social Inclusion, Social Capital and Immigration,” Canadian Issues (April 2003).
} 
In addition to exclusion in the economic and political dimensions of life, many Canadian immigrants experience social exclusion, in the form of social isolation, cultural isolation, and lack of access to public services. Nadia Caidi and Danielle Allard explore the question of whether the social inclusion or exclusion of immigrants is an issue related to access, or lack thereof, to informational services, including English as a Second Language (ESL) classes, and other services that relate to housing, employment and education opportunities, and health care. When these needs are not easily met by newcomers, their feelings of inclusion and belonging are very likely to suffer. ${ }^{51}$ These authors argue that the rethinking of social inclusion in terms of access to information, and the skills and literacy required to interact with that information, is key to ensuring immigrants' social capital. They discuss the concept of the 'digital divide', the factors which make access to mainstream information by vulnerable populations difficult. In the case of new immigrants, these risk factors are exacerbated when considering that many are members of visible minority groups, are not proficient in English or French, live in particular lower class neighbourhoods, have low income, and may have children at higher risks of schooling problems..$^{52}$ This argument addresses not only the inclusion of newcomers, but of all Canadians who depend on public resources to engage with their communities and discover how to access the services required to meet their own social, economic and political needs.

Other scholars find that another way to foster social inclusion among immigrants is through the participation in cultural programs and the arts. Huong Le et al. examine the causes and consequences of newcomer under-participation in leisure and arts activities. The authors

\footnotetext{
${ }^{51}$ Nadia Caidi and Danielle Allard, Social Inclusion of Newcomers to Canada: An Information Problem? CERIS Policy Matters, No. 23, 2005: 303.

${ }^{52}$ Caidi and Allard, Social Inclusion of Newcomers, 314.
} 
argue that participation can contribute to the process of social inclusion, as immigrant groups can use art as a way to balance old home country values and behaviours, while adopting the values and behaviours of their new home country. ${ }^{53}$ In this way, the arts may reduce social isolation, and facilitate social cohesion and connectedness. Similarly, Shawn D. Forde et al. argue that social inclusion may be promoted through the use of community sport and recreation programs. The authors argue that these services can act as primary sites for recent immigrants to connect with their neighbours and learn more about their new community, reduce feelings of social isolation and exclusion, and participate in health-promoting activities. ${ }^{54}$ These authors note that, while many newcomers want to learn about new sports to help connect with and adapt to their new communities, many may also want to retain and share their own physical cultures. This two-way process allows newcomers to learn new activities while teaching their own traditions to nativeborn residents, fostering mutual learning and cross-cultural understanding. ${ }^{55}$

The concept of social inclusion is often equated with the policy of multiculturalism, citing its success with integrating newcomers. However, Reitz and Banerjee challenge this view on the basis that multiculturalism has not ensured the same progress for racial minorities as it has for white immigrant groups. The authors also challenge the view that racial discrimination is not a significant problem in Canada, arguing that this perspective contributes to the belief that existing government policies are working, and that reform, and consequently further research, is not necessary. Reitz and Banerjee argue that if those in power consider existing policies, such as

\footnotetext{
${ }^{53}$ Huong Le, Michael Polonsky, and Rodney Arambewela, "Social Inclusion Through Cultural Engagement Among Ethnic Communities," Journal of Hospitality Marketing \& Management 24 (2015): 378-380.

${ }^{54}$ Shawn D. Forde, Donna S. Lee, Cathy Mills, and Wendy Frisby, "Moving Towards Social Inclusion: Manager and Staff Perspectives on an Award Winning Community Sport and Recreation Programs for Immigrants," Sport Management Review 18 (2015): 127.

${ }^{55}$ Forde et al., "Moving Towards Social Inclusion," 128.
} 
multiculturalism, to be sufficient to maintain what most Canadians believe to be a fair and equitable society for immigrants and minorities, inequality and racial discrimination will persist. ${ }^{56}$

The concept of social inclusion embodies many of the elements required for newcomer integration in Canada (including Quebec), such as economic success, employment, civic engagement, participation in community activities, and racial equality. Although all these factors may not encompass or represent all the integration challenges faced by immigrants and minorities, it does help us better understand the problem, and provides a further framework with which we can compare multiculturalism and interculturalism.

\section{Literature Review}

There is a large body of literature concerning Canadian multiculturalism, and a rapidly growing body on interculturalism in Quebec. This review includes scholarly works and government documents, mostly published in English, which examine Canada's official multiculturalism policy and Quebec's informal interculturalism policy; their origins, strategies for newcomer integration, and the criticisms mounted against each. The first section of this literature review will focus on multiculturalism more broadly, mainly as a policy and tool of diversity, as well as recent research which evaluates its shortcomings. The bulk of this review will examine the distinct case of Quebec, and the rise of interculturalism as its unofficial policy, including the province's distinct culture and history, followed by an overview of the BouchardTaylor Commission. This literature review will complement my further research by providing

\footnotetext{
${ }^{56}$ Reitz and Banerjee, "Racial Inequality”, 152.
} 
some much-needed context that will allow me to compare multiculturalism and interculturalism through the examination of immigrant outcomes in Toronto and Montreal.

\section{The Policy of Multiculturalism: History and Practice}

Canada $^{57}$ was the first Western country to adopt multiculturalism as an official policy in 1988, and remains the only country in which multiculturalism is enshrined in the constitution. Canada is one of the most successful multicultural nations, as immigrants in Canada are more likely to become citizens, and to vote, run for, and be elected for office than immigrants in any other Western democracy; the children of immigrants have better educational outcomes than their counterparts in other Western democracies; and Canadians are more likely to say that immigration is beneficial, and less likely to have prejudiced views of Muslims. ${ }^{58}$ While these factors are not the only measures of multiculturalism's success, they do have a significant impact on the inclusion and integration of recent and established immigrants across the country.

To many scholars, multiculturalism is a label to describe pluralism and diversity within a society, while at the same time providing the moral stance that cultural diversity is a desirable feature of that society. ${ }^{59}$ To Vic Satzewich and Nikolaos Liodakis, multiculturalism has four interrelated meanings:

\footnotetext{
${ }^{57}$ In this literature, when referring to Canada, I mean Canada with the inclusion of the province of Quebec, unless otherwise specified.

${ }^{58}$ Will Kymlicka, Multiculturalism: Success, Failure, and the Future (Washington, D.C.: Transatlantic Council on Migration, Migration Policy Institute, 2012), 10-11.

${ }^{59}$ Nasar Meer and Tariq Modood, "How Does Interculturalism Contrast with Multiculturalism," Journal of Intercultural Studies 33 no.2 (2012), 179.
} 
1. Multiculturalism is a demographic reality, as the Canadian population is comprised of over 100 ethnic groups, and was multicultural long before the implementation of the 1971 policy.

2. Multiculturalism is part of a pluralist ideology, in which individuals have the right to self-identify and promote their own culture, while extending those same rights to individuals who share different cultural norms and values.

3. Multiculturalism was created as a process of conflict resolution, an attempt to mediate competition between ethnocultural groups for access to political and economic resources.

4. Multiculturalism is a set of government policies and initiatives that attempt to accommodate and reconcile social differences, maintain the existing social order, and manage social change, all within the framework of a culturally diverse society. ${ }^{60}$

The second meaning, which supports the acceptance and promotion of the many cultures in Canada, is most aligned with my own understanding of multiculturalism, as it relates to this paper, viewing multiculturalism more as an ideology shared by Canadians, rather than a policy enforced by Canadians.

As we will see, the policy of multiculturalism in Canada has a relatively long history that is not without its challenges, many of which provide the catalyst for the later introduction of interculturalism in Quebec. Since multiculturalism's establishment, the policy has undergone numerous changes with regards to meaning and policy, but continues to assert the equality and recognition of all cultures.

\footnotetext{
60 Vic Satzewich and Nikolaos Liodakis, "Race” and Ethnicity in Canada: A Critical Introduction, Third Edition (Toronto: Oxford University Press, 2013), 161-162.
} 


\section{Creation as a Policy}

Official discourse on diversity in Canada originated from policy documents produced by the federal government in the 1960s, the first of which was the multi-volume Report of the Royal Commission on Bilingualism and Biculturalism (B \& B Report), published from 1963 to 1967. At the time, the federal government recognized that it needed to address the rise in Quebec nationalism through the Quiet Revolution. The commission's mandate was to “inquire into and report upon the existing state of bilingualism and biculturalism in Canada and to recommend what steps should be taken to develop that Canadian Confederation on the basis of an equal partnership between the two founding races, taking into account the contribution made by the other ethnic groups to the cultural enrichment of Canada". ${ }^{61}$ The two founding races being, of course, the English and French.

The Commission's Preliminary Report contains one of the earliest uses of the term "multiculturalism" in a public document. The Report included a section entitled The Cultural Contribution of the Other Ethnic Groups, which limited its study to "the part played by these groups in the country's history and the contribution they make to daily life". ${ }^{62}$ However, this form of multiculturalism referred mostly to the situation of Canadians of European descent, rather than those of Sikh or Muslim origins. ${ }^{63}$ After years of public hearings, consultations and research, the Royal Commission published its final report and made several recommendations to the government, including instituting both French and English as Canada's official languages,

\footnotetext{
${ }^{61}$ Government of Canada, Report of the Royal Commission on Bilingualism and Biculturalism. General Introduction, Book I: The Official Languages (1967),173. Accessed at: http://epe.lac-bac.gc.ca/100/200/301/pcobcp/commissions-ef/dunton1967-1970-ef/dunton1967-70-vol1-eng/dunton1967-70-vol-part2-eng.pdf.

${ }^{62}$ Day, Multiculturalism, 187.

${ }^{63}$ Maxwell Yalden, "Multiculturalism: An Anniversary Celebration," Canadian Ethnic Studies 43 no.1 (2011), 7.
} 
which Liberal Prime Minister Pierre Trudeau's government implemented in 1969 with the Official Languages Act. ${ }^{64}$ The Canadian government recognized the need for a bilingual Canada, but not necessarily a bicultural Canada.

The official adoption of multiculturalism was announced in October of 1971 by Trudeau. In his statement to the House of Commons, Trudeau emphasized that "there cannot be one cultural policy for Canadians of British and French origin, another for the original peoples and yet a third for all others. For although there are two official languages, there is no official culture" ${ }^{65}$ His famous speech stated that every citizen had the right and freedom to preserve his or her own culture, emphasizing equality, democracy and diversity. ${ }^{66}$ However, by refusing to hierarchize the English or French cultures in Canada, this statement also alienated many Quebecers. For scholars like Gérard Bouchard, by purposefully omitting any recognition of Quebec's status as a founding nation, Francophones were now to be counted as just one ethnic group among many. Bouchard argues that multiculturalism had been designed for an Anglophone Canada, with little, if any, attention paid to the French national minority. ${ }^{67}$ For this reason, multiculturalism was fiercely opposed by many within Quebec; a legacy that, as we will see below, continues today.

With the adoption of the Canadian Charter of Rights and Freedoms in 1982, multiculturalism became officially enshrined in the Constitution, making Canada the first nation to pass multiculturalism into national law. Section 27 states that the Charter "shall be interpreted

\footnotetext{
${ }^{64}$ Day, Multiculturalism, 182.

${ }^{65}$ Yalden, "Multiculturalism", 7.

${ }^{66}$ Day, Multiculturalism, 188-189.

${ }^{67}$ Bouchard, Interculturalism, 60.
} 
in a manner consistent with the preservation and enhancement of the multicultural heritage of Canadians", empowering courts to take multiculturalism into consideration at the highest level of decision-making. ${ }^{68}$ Additionally, the Charter guarantees the equality of all individuals before the law, regardless of race, national or ethnic origin, and religion, and protects individuals' freedom of expression, while protecting against racial slurs or racially-based hate propaganda. ${ }^{69}$ Adopted in 1988 by the Conservative government of Prime Minister Brian Mulroney, the Multiculturalism Act solidified Canada's commitment to multiculturalism, which pledges to encourage the full participation of all individuals in Canadian society, regardless of differences of racial, ethnic or national origin, and to help individuals overcome discriminatory barriers based on those differences. ${ }^{70}$

Since the Act, the federal government has made numerous efforts to support these principles, including establishing the Department of Multiculturalism and Citizenship in 1991 (although responsibility for multiculturalism has been passed between several departments over the years, it now lays under the purview of the Department of Canadian Heritage); creating the Canadian Race Relations Foundation in 1997; signing several UN Conventions concerning cultural diversity; designating June 27 of each year as Canadian Multiculturalism Day in 2002; and launching several internal evaluations into Canada's multiculturalism policy, in order to measure its effectiveness, gauge public opinion, and formulate any recommendations to improve its implementation. ${ }^{71}$ At a provincial level, all ten provincial governments have adopted some

\footnotetext{
${ }^{68}$ Michael Dewig, Canadian Multiculturalism, Background Paper (Ottawa: Library of Parliament, 2013), Publication No. 2009-20-E, 4.

${ }^{69}$ Dewig, Canadian Multiculturalism, 4.

${ }^{70}$ Yalden, "Multiculturalism", 8.

${ }^{71}$ Dewig, Canadian Multiculturalism, 5-8.
} 
form of multicultural policy, and although the territories do not, each has a human rights act that prohibits discrimination based on race, religion, and ethnic or national origin, among other things. $^{72}$

Over the course of multiculturalism's history in Canada, there have been four overlapping stages and principles that guided federal conceptions of multiculturalism. Each of these stages involved subtle changes and adjustments to both the policy itself, and meanings associated with the policy. ${ }^{73}$ The 1970 s were characterized by ethnicity multiculturalism, which celebrated cultural differences and focused on cultural sensitivity and the cultural mosaic. This period focused on celebrating differences, as individuals were encouraged to cultivate and promote their cultures and participate in all facets of Canadian life. ${ }^{74}$ Equity multiculturalism gained traction in the 1980s, which recognized the need to acknowledge and address systemic discrimination experienced by visible minority groups to create a more equitable society. Greater equality through multiculturalism was considered to be increasingly positive for Canada, both in terms of a pluralist ideology, but also as an economic asset. The greater involvement of immigrants in the labour market could translate to increased business, prosperity, and international trade, particularly within the emerging global economy. ${ }^{75}$

The 1990s saw a move towards civic multiculturalism, focusing on citizenship, belonging and greater civic engagement in one's community. A major focus of this period was society-

\footnotetext{
${ }^{72}$ Dewig, Canadian Multiculturalism, 10.

${ }^{73}$ Satzewich and Liodakis, "Race" and Ethnicity in Canada," 162-164.

${ }^{74}$ Scott Schaffer, "Cosmpolitanizing Cosmopolitanism? Cosmopolitan Claims Making, Interculturalism, and the Bouchard-Taylor Report," in Rooted Cosmopolitanism: Canada and the World, ed. Will Kymlicka and Kathryn Walker (Vancouver: UBC Press, 2012), 141; Satzewich and Liodakis, "Race" and Ethnicity, 162-163.

${ }^{75}$ Schaffer, "Cosmpolitanizing Cosmopolitanism?," 141; Satzewich and Liodakis, "Race” and Ethnicity, 163.
} 
building, promoting a common sense of identity and belonging among all citizens that was considered crucial to the participation of Canadians in national institutions, like government. This form of multiculturalism was reciprocal; institutions needed to change in order to better reflect Canada's increasingly diverse society, and in return, Canadians needed to change by becoming more involved citizens. ${ }^{76}$ In the 2000 s, integrative multiculturalism became the dominant model, initiating a discourse of rights and responsibilities for all Canadians and encouraging increased dialogue and mutual understanding. This current phase focuses on the 'duty' of immigrants and members of ethnic communities to better integrate and adopt Canadian values. $^{77}$

\section{$\underline{\text { Criticisms of Multiculturalism }}$}

Since its institution in 1971, Canadian multiculturalism has been challenged by critics, both within Canada and without. On a global scale, criticism of multiculturalism has mounted in the last two decades as many European countries like Germany and the United Kingdom have begun to move away from the multicultural rhetoric. Some leaders claim that multiculturalism is not an effective integration tool for immigrants as it does not foster a mainstream identity to which immigrants can feel they belong. ${ }^{78}$ Will Kymlicka counters these claims, arguing that these public condemnations of the policy are more talk than action, serving a political purpose. By denouncing the multicultural past, leaders can then submit their own suggestions as

\footnotetext{
76 Schaffer, “Cosmpolitanizing Cosmopolitanism?," 141; Satzewich and Liodakis, "Race” and Ethnicity, 164.

77 Schaffer, “Cosmpolitanizing Cosmopolitanism?," 141; Satzewich and Liodakis, “Race” and Ethnicity, 164.

${ }^{78}$ Satzewich and Liodakis, “Race” and Ethnicity, 159-160.
} 
innovative, becoming champions of the cause. ${ }^{79}$ Charles Taylor argues likewise, that antimulticultural rhetoric in Europe fundamentally misunderstands the dynamics of ethnic communities in the West, and that the strategy of 'tough love' will neither encourage them to want to integrate, nor will it encourage the wider population to accept them. ${ }^{80}$

Broadly, there are two types of criticisms of multiculturalism, one which argues that the policy is ineffective in addressing Canada's growing diversity by ignoring issues of race, class and the Anglo-dominant culture, and another which argues that it is too effective, and as a result has entrenched stereotypes, undermined Canadian values, and for some scholars, indirectly creates an avenue for the spread of violence and terrorism. ${ }^{81}$ For those scholars and politicians who claim multiculturalism is ineffective, one of the main faults of the policy is in its hands-off approach to addressing diversity. Kymlicka, one of Canada's leading multiculturalism scholars, admits that multiculturalism tends to over-emphasize the celebratory model of diversity, in which minority cultures are celebrated on a surface level, particularly in terms of clothing, cuisine and music (the three "S's": saris, samosas, and steel bands). ${ }^{82}$ However, these celebrations do little to address the racial, economic and political issues faced by these communities. Kymlicka suggests that this model can end up reinforcing power inequalities and cultural restrictions within and between minority groups. ${ }^{83}$ Similarly, Grace-Edward Galabuzi argues that Canadian multiculturalism policy was created with an inclusive framework in mind, but did not fully break

\footnotetext{
${ }^{79}$ Kymlicka, Multiculturalism, 15.

${ }^{80}$ Charles Taylor, “Interculturalism or Multiculturalism?” Philosophy and Social Criticism 38 no.4-5 (2012), 414.

${ }^{81}$ An overview of these criticisms can be found in Satzewich \& Liodakis, "Race" and Ethnicity, 165-178.

${ }^{82}$ Will Kymlicka, Multiculturalism, 4.

${ }^{83}$ Ibid., 4.
} 
from the monocultural concept of Canadian society, glossing over some of the unique problems faced by some cultures. The existing policy presents itself as neutral, and equates the experiences of all cultural groups, and does not recognize their differences. In doing so, Galabuzi claims, multiculturalism obscures differences of class, race, and gender, not acknowledging that these are key determinants to "marginalization, structural oppression, exploitation and exclusion faced by racialized people in Canada" ${ }^{84}$

Richard J.F. Day finds fault with modern government discourse on multiculturalism, which suggests that Canada as a multicultural utopia is an already achieved ideal, rather than a work in progress. ${ }^{85}$ By perpetuating this belief among those with decision-making powers, and consequently onto the public, the government can unburden itself from the responsibility of committing more resources to rectify inequalities, and does not feel the need to amend the decades-old Multiculturalism Act. ${ }^{86}$ To Augie Fleras, multiculturalism is an irrelevant policy, at least in its current form, due to its intrinsic flaws. On the one hand, any multiculturalism that highlights serious differences between groups is accused of compromising commitments to equality, inclusion, and social unity. Meanwhile, a policy that does not recognize these differences may have the unintended effect of reinforcing the status quo, and further marginalizing minority groups. ${ }^{87}$

\footnotetext{
${ }^{84}$ Grace-Edward Galabuzi, "Hegemonies, Continuities, and Discontinuities of Multiculturalism and the AngloFranco Conformity Order," in Home and Native Land: Unsettling Multiculturalism in Canada, ed. by May Chazan et al. (Toronto: Between the Lines, 2011), 74-75.

85 Day, Multiculturalism, 6.

${ }^{86}$ Ibid., 7.

${ }^{87}$ Fleras, Racisms in a Multicultural Canada, 243.
} 
Meanwhile, those critics who claim that multiculturalism is too effective, focus on the negative social effects that the policy has produced, rather than the social conditions it has ignored. Among these critics are those who consider multiculturalism to be an affront to the special rights of Indigenous peoples and Quebecers, which will be discussed in the following sections. One of these scholars is Neil Bissoondath who, after the publishing of his 1994 book Selling Illusions: The Cult of Multiculturalism in Canada, caused quite the media stir because he himself is a member of a visible minority group. He argues that multiculturalism reduces citizens to the lowest common denominator, entrenching ethnic and racial stereotypes, thus simplifying and devaluing minority cultures. ${ }^{88}$ This argument is closely related to Kymlicka's stance that multiculturalism often tends to assume that cultural traditions and practices are static, ignoring the evolution process that occurs over time, the longer a community has been in Canada, and as that culture interacts and mixes with others. ${ }^{89}$

Another criticism from this camp claims that multiculturalism is failing, as it is too tolerant, indirectly promoting cultures and religions that are themselves discriminatory and ignorant, and laying the groundwork for homegrown terrorism. This viewpoint appears much less popular than all the others previously mentioned, as I could find little academic research that supports the idea that multiculturalism isolates some communities to the point where they may become radicalized. ${ }^{90}$ While this argument is controversial, it is an important one to discuss, and perhaps further research on multiculturalism can examine the relationship between the two concepts.

\footnotetext{
88 Satzewich and Liodakis, “Race” and Ethnicity, 169.

${ }^{89}$ Kymlicka, Multiculturalism: Success, Failure and Future, 5.

90 Satzewich and Liodakis, "Race” and Ethnicity, 175.
} 
Many of multiculturalism's critics are also supporters of the policy, however they wish for an improved version or different measures of implementation to reduce barriers to discrimination and to promote a Canadian identity. Meanwhile, many other critics believe that the policy's principles are fundamentally inconsistent with the realities of their own society, and it is this belief that has led many scholars and decision-makers in search of an alternative to multiculturalism.

\section{Limits to the Practice of Multiculturalism?}

Multiculturalism as a policy and multiculturalism as a practice may not always be the same thing. While Canadian multiculturalism was established as an effort to manage the country's diversity, and reduce discrimination among minorities, this discrimination has yet to be overcome, as evidenced by the political and public debates of the 2015 federal election, during which issues concerning diversity, religion, and the accommodation of minorities played a significant role. Leading up to the election, the Zero Tolerance for Barbaric Cultural Practices Act was passed into law in June, with the governing Conservatives and Liberals voting in favour, and the New Democrats and Green Party opposed. The Act proposed changes to the Immigration and Refugee Protection Act, the Civil Marriage Act and the Criminal Code by preventing the immigration of those who practice polygamy, and criminalizing child marriage and forced marriage, all of which were already illegal in Canada. ${ }^{91}$ The Act also limits the defence of provocation so that it does not apply to honour-killings and many cases of spousal homicide. The

\footnotetext{
${ }^{91}$ Ashley Csanady, “'Barbaric Cultural Practices' bill to criminalize forced marriage, tackle 'honour killings' passes final vote", The Globe and Mail, June 17, 2015, accessed April 9, 2016, http://news.nationalpost.com/news/canada/ canadian-politics/barbaric-cultural-practices-bill-to-criminalize-forced-marriage-tackle-honour-killings-set-for-finalvote.
} 
stated objectives of the Act included "improved protection and support for vulnerable women, primarily immigrant women and girls". ${ }^{92}$ The discourse of this legislation implies that immigrant women and girls are more vulnerable than those born in Canada, ostensibly due to their "barbaric cultural practices". This pointed aim at ethnic and religious minorities in Canada was introduced by the Conservatives during the election period, further polarizing the electorate. The Act's supporters heralded the government as a champion of Canadian values, while its critics maintained that the Act was a timed effort to inflame tensions and divide Canadians for political gain. ${ }^{93}$

Following this debate, the country's focus turned to the plight of Syrian refugees after photographs of a drowned toddler lying on a Turkish beach emerged in September 2015. These photos drew international attention, and many Canadians demanded that the government do more to assist these refugees. Criticism mounted after it was revealed that the Kurdi family's application for asylum had been denied by the Canadian government, prompting the family's decision to flee. ${ }^{94}$ Further debate ensued regarding, on the one hand, Canada's commitment to refugees, and on the other, Canada's commitment to national security. Concerns that the expedited processing of refugee claims would allow Islamic terrorists into the country seemed to permeate all public discussions about Canada's responsibility to both refugees and its citizens..$^{95}$

\footnotetext{
92 “Archived - Zero Tolerance for Barbaric Cultural Practices Act receives Royal Assent”, News Release, Government of Canada. http://news.gc.ca/web/article-en.do?nid=989099.

${ }^{93}$ Eric Andrew-Gee, "Conservatives Vow to Establish 'Barbaric Cultural Practices' Tip Line”, The Globe and Mail, October 2, 2015, accessed July 7, http://www.theglobeandmail.com/news/politics/conservatives-vow-to-establishbarbaric-cultural-practices-tip-line/article26640072/.

${ }^{94}$ Aileen Donnelly, “Alan Kurdi's father blames Canada for death of his family as PM suggests he will expedite refugee applications", National Post, September 10, 2015, accessed April 9, 2016, http://news.nationalpost.com/ news/canada/alan-kurdis-father-blames-canada-for-death-of-his-family-as-pm-suggests-he-will-expedite-refugeeapplications.

${ }^{95}$ Ibid.
} 
However, possibly the most divisive debate of the elections involved one Muslim woman's right to wear her niqab during her citizenship ceremony. Zunera Ishaq, the woman at the centre of the controversy, had challenged the ban on the niqab, which was instated in 2011, and won her challenge in 2014. The government lost several appeals, and in mid-September of 2015, the federal court rejected an appeal by then-Prime Minister Stephen Harper's government which attempted to prevent Zunera Ishaq from swearing her oath with her face veil. The first court ruling declared the attempted ban as "unlawful". ${ }^{96}$ Public opinion was deeply divided on this issue, while a poll ordered by Harper's government showed that 82 percent of respondents agreed with the niqab ban at citizenship ceremonies, while 18 percent opposed the ban.${ }^{97}$ It was during this time that the issue of immigrant culture resurged, as the Conservatives proposed the establishment of a telephone hotline where citizens could report suspicions of "barbaric cultural practices" committed by neighbours. ${ }^{98}$

Ultimately, the Conservatives were defeated, and the Liberals' inclusive rhetoric won its representatives a majority government. ${ }^{99}$ The negative perceptions of ethnic and religious minorities expressed during the election are not in agreement with the fundamentals of multiculturalism, which promotes equality, tolerance, and protection against discrimination. While there is no existing research which specifically links multiculturalism to these perceptions, this section is meant to highlight that many of the opinions manifested in Quebec leading up to

\footnotetext{
${ }^{96}$ Ishaan Tharoor, "How a Muslim veil is dominating Canada's election race", The Washington Post, October 5, 2015, accessed April 9, 2016, https://www.washingtonpost.com/news/worldviews/wp/2015/10/05/how-a-muslimveil-is-dominating-canadas-election-race/.

${ }^{97}$ Dean Beeby, "Poll ordered by Harper found strong support for niqab ban at citizenship ceremonies", CBC News, September 24, 2015, accessed April 9, 2016, http://www.cbc.ca/news/politics/canada-election-2015-niqab-pollpco-1.3241895.

${ }^{98}$ Eric Andrew-Gee, "Conservatives Vow to Establish 'Barbaric Cultural Practices' Tip Line”.

${ }^{99}$ Blatchford, "Justin Trudeau in Victory Speech."
} 
and during the Bouchard-Taylor Commission, and from the proposal of Quebec's Charter of Values, are not unique to Quebec, but are also present across the rest of Canada.

The Policy of Interculturalism: How Quebec Got to Now

Interculturalism seemingly presents the alternative to multiculturalism. Quebec's immigration and integration policies have differed from those in the rest of Canada for several decades now, although interculturalism has never been officially adopted by the Quebec government. These two distinct nation-building policies emerged out of efforts to manage increasingly diverse populations. While the Canadian Multicultural Act specified that no official national culture exists in Canada, Quebec has made numerous efforts to assert the national French culture and identity. Quebec's priorities concerning the admission and integration of newcomers in the province highlight the general concerns that many Quebecers have about the future of the Quebec culture; the higher points allotted to French-speaking applicants emphasizes the importance of the survival of the French language, while the emphasis on the Quebec culture as the focus of convergence for minority cultures emphasizes that the Quebec nation remains a founding nation.

\section{The Evolution of L'interculturalisme}

Quebec's informal policy of interculturalism purposefully differs from the national discourse of multiculturalism, in an effort to preserve the Quebec identity, while still working to respect the diversity of its immigrants. For much of Quebec's history prior to the 1960s, the province was largely culturally homogenous. Dominated by traditional religious social controls, 
conservative political leadership that largely resisted liberal economic reforms, and Anglophone control over much of Montreal's commercial and financial areas, immigration to Quebec was not necessary for economic growth, nor was it desired in a largely rural, agrarian economy. ${ }^{100}$ The divergence from this traditional system began with the Quiet Revolution, the redefinition of the French Canadian nation beginning in the early 1960s, characterized by the celebration of the French culture and language, the erosion of public support for the Catholic church, and, among other changes, the secularization of the educational system, reform of the civil service, and nationalization of many sectors of Quebec's economy. ${ }^{101}$

Following the release of the $B \& B$ Report, and Pierre E. Trudeau's decision not to recognize Canada as bicultural as well as bilingual, the Quebec government pushed to carve out its own political space. The first effort made by the Quebec government to become actively involved in immigration policy-making was the creation of Quebec's Ministry of Immigration in 1968 through Bill 75. The Bill gave the ministry three duties: "to encourage the settlement of immigrants likely to contribute to Quebec's development... to encourage the adaption of immigrants to the Québécois milieu and... to encourage the preservation of immigrants' ethnic customs". ${ }^{102}$ The creation of the Ministry came at an important time in Quebec, in the wake of the Quiet Revolution, and as leaders perceived that the province was experiencing a demographic crisis. As Parti Québécois leader René Lévesque claimed, new immigrants were likely to integrate into Anglophone society rather than Francophone, posing a threat to the future and

\footnotetext{
${ }^{100}$ Cory Blad and Philippe Couton, "The Rise of an Intercultural Nation: Immigration, Diversity and Nationhood in Quebec," Journal of Ethnic and Migration Studies 35, no.4 (April 2009), 655.

${ }^{101}$ Satzewich and Liodakis, "Race" and Ethnicity, 66.

102 Barker, "Learning to be a Majority," 20.
} 
preservation of the Quebec nation. ${ }^{103}$ In 1977, the Quebec government adopted the Charter of the French Language (Bill 101), formally establishing French as Quebec's official language of governance and daily life, and affirming the government's commitment to its Francophone history and culture. The Bill also stated the government's commitment to ethnic minorities, while encouraging them to integrate into the francophone minority. ${ }^{104}$ Jean-François Dupré argues that by designating French as the main identity marker in Quebec, rather than Catholicism or French ancestry, Bill 101 de-ethnicized the French language. Effectively, an individual could consider themselves a Quebecer if they lived in and spoke the shared language of Quebec, promoting civic nationalism. ${ }^{105}$ Quebec's government took many steps towards promoting successful integration and fighting discrimination. For example, enshrined in the Quebec Charter of Rights and Freedoms, adopted in 1975, individuals belonging to ethnic minorities have the right to maintain and develop their own cultural interests, as well as have equal access to employment, free from discrimination based on race or ethnic origin. ${ }^{106}$

Cory Blad and Philippe Couton argue that the greatest threat to Quebec nationalists, and the nationalist cause, is the domination of Anglo-Canada over Quebec culture. As a result, nationalists have gradually developed an immigration policy to manage ethnocultural diversity,

\footnotetext{
103 Barker, "Learning to be a Majority," 20.

104 François Rocher, Micheline Labelle, Ann-Marie Field, Jean-Claude Icart, Le concept d'interculturalisme en contexte québécois: Généalogie d'un néologisme, Centre de recherche sur l'immigration, l'ethnicité et la citoyenneté, Rapport présenté à la Commission de consultation sur les pratiques d'accommodement reliées aux différences culturelles, December 2007, 5.

105 Jean-François Dupré, “Intercultural Citizenship, Civic Nationalism, and Nation Building in Québec: From Common Public Language to Laïcité," Studies in Ethnicity and Nationalism 12 no. 2 (2012), 236.

106 Quebec Charter of Rights and Freedoms, Part I, 1975, s 43; Quebec Charter of Rights and Freedoms, Part III, 1982 , s 86.
} 
while strengthening the French language and preserving nationalist goals. ${ }^{107}$ Within the province, there was the widespread belief that anglophone and allophone (immigrants whose first language is neither French nor English) immigration to Quebec was flooding communities, and with the election of the PQ in 1976, the government officially terminated English-language classes for immigrants. ${ }^{108}$ The government was further empowered by the 1978 Cullen-Couture Agreement, which allowed the province to set its own objectives regarding the volume and composition of immigrants to Quebec. By the following year, about 90 percent of economic immigrants to Quebec were admitted based on the province's selection criteria, as opposed to just 18 percent the year before. ${ }^{109}$

The 1991 Canada-Quebec Accord gave Quebec the exclusive right to select its economic immigrants, giving greater weight to knowledge of French language in an effort to slow the increase of the non-Francophone population. The privileging of French-speakers, regardless of ethnic or cultural background, would indirectly favour non-European applicants, besides those from French-speaking nations. Consequently, there was a rapid decrease in immigrants coming from Asia, as well as a more gradual increase of immigrants from Africa, the Middle East, and the Caribbean, particularly from former French colonies like Haiti, Algeria and Morocco. ${ }^{110}$ The Accord also gave greater power to the province to direct its own immigrant integration policies, an important aspect of bringing newcomers into Quebec's nation-building process. ${ }^{111}$ Following

\footnotetext{
${ }^{107}$ Blad and Couton, "The Rise of an Intercultural Nation," 660.

${ }^{108}$ Ninette Kelley and Michael Trebilcock, The Making of the Mosaic: A History of Canadian Immigration Policy (Toronto: University of Toronto Press, 2010), 387.

${ }^{109}$ Barker, "Learning to be a Majority," 22.

${ }^{110}$ Blad and Couton, “The Rise of an Intercultural Nation," 654; Dupré, "Intercultural Citizenship,” 236.

${ }^{111}$ Barker, "Learning to be a Majority," 23.
} 
the Canada-Quebec Accord, the federal government passed responsibility for immigrant integration to the province, withdrawing from all settlement and integration programmes in Quebec. ${ }^{112}$

Most scholars agree that the official foundations of Quebec's current interculturalist policy were laid in the 1981 Autant de façons d'être Québécois : plan d'action du gouvernement du Québec à l'intention des communautés culturelles (So Many Ways to be Quebecers: Action Plan for Cultural Communities). The report states that, rather than the "melting pot" of the United States or the "Canadian mosaic" promoted by the federal government, Quebec's preferred model involves the convergence of other cultural traditions around the French tradition. ${ }^{113}$ This does not mean that immigrants were meant to assimilate to the French culture; rather, immigrants were encouraged to view Quebec culture, and particularly the French language, as the meeting place of a shared culture among all citizens. This exchange became understood in Quebec as the province's moral contract. ${ }^{114}$ The notion of the moral contract, a contract between immigrants and the wider Quebec society based on a shared French culture, first appeared in the 1990 document Let's Build Quebec Together: A Policy Statement on Immigration and integration. The document laid out three elements that define Quebec society:

1. A society in which French is the common language of public life.

2. A democratic society that expects and encourages everyone to participate and contribute.

\footnotetext{
112 Barker, "Learning to be a Majority," 26.

113 Rocher et al., Le concept d'interculturalisme, 8-9.

114 Bouchard, Interculturalism, 31.
} 
3. A pluralistic society that is open to outside contributions, within the limitations imposed by respect for basic democratic values and the need for inter-community exchange. ${ }^{115}$ Interestingly, the document, published just two years after the adoption of the Multiculturalism Act, also emphasized Quebec's need to increase its immigration levels to address the province's demographic, cultural, economic, and linguistic difficulties, confronting Quebec's challenges and embracing pluralism. ${ }^{116}$

Following Bill 101, Quebec's government made increased efforts to promote newcomer integration, particularly through the use of French language education. While children are made to learn and practice French in schools, there exists no mandatory policies for adults concerning French language proficiency. Beginning in the late 1980s, the Programme of Assistance for the Francization of Immigrants was launched, becoming the first program funded entirely by Quebec, as well as a series of entitlements for adult immigrants, including the right to 600-hours of full-time free French classes following their arrival in Quebec. ${ }^{117}$ This rise in resources corresponded with a decrease of funding for immigrants' home language classes, which had the effect of increasing the number of immigrant allophones who reported having integrated to French, rather than English. ${ }^{118}$

While these policies appeared to be addressing Quebec's linguistic needs, the province's faith in interculturalism suffered a blow following the loss of the second referendum on Quebec sovereignty in 1995, by 0.3 percent of the vote. Afterwards, PQ leader and Premier Jacques

\footnotetext{
115 Bouchard, Interculturalism, 30.

${ }^{116}$ Dupré, "Intercultural Citizenship," 237.

117 Barker, "Learning to be a Majority,” 30.

${ }^{118}$ Ibid., 30.
} 
Parizeau famously said that sovereignty had been defeated by 'money and the ethnic vote', which voted 90 percent against secession. ${ }^{119}$ Parizeau was widely criticized for this statement in both public and political spheres, demonstrating that such discourses were not politically acceptable. Following the referendum, Quebec's political parties made an increased effort to bring together the Francophone majority and ethnic minorities, while new discourses emerged to encourage the creation of Quebec's united political community. ${ }^{120}$ These discourses persist today, as Quebec's interculturalism policy continues to evolve and take new shape, while the nationalist sentiment lives on. In 2006, the Canadian Parliament passed a motion that recognized the Quebec people as a distinct nation within the Canadian nation-state. While this motion was largely symbolic and was not accompanied with any change in the province's power within Canada, it does demonstrate the persistent power of Quebec nationalism. ${ }^{121}$

\section{Contemporary Interculturalism in Quebec}

The ideals of interculturalism has persisted in Quebec for over twenty years, although it had always been ill-defined and lacked a solid integration framework. How do modern Quebec scholars and politicians understand interculturalism today? Literature concerning interculturalism, particularly interculturalism in Quebec, remains relatively limited to scholars from the province itself, and a few within Canada who examine its relationship with multiculturalism. However, considering this small community, the topic has sparked some debate, with strong arguments at both ends of the spectrum. Supporters cite the supposed failure

\footnotetext{
119 Banting and Soroka, "Minority Nationalism," 159.

${ }^{120}$ Dupré, “Intercultural Citizenship,” 237.

${ }^{121}$ Blad and Couton, "The Rise of an Intercultural Nation," 662.
} 
of the ideals of multiculturalism in Quebec, claiming that the equal celebration of all cultures is just not consistent with Quebec's distinct history and language, and present interculturalism as the ideal alternative for managing the province's growing diversity. Critics contend that interculturalism subjugates minority cultures within the Francophone majority, undermining both the successful integration of immigrants and Quebec society as a whole through fragmentation.

Gérard Bouchard, a Quebec scholar and co-chair of the Bouchard-Taylor Commission, describes interculturalism as a model based on a search for balance that attempts to find a middle ground between assimilation and segmentation. Important components of Quebec's interculturalism include the promotion of French as the main language of civic life, and an emphasis on three interwoven identities: the Francophone majority culture, ethnic minority cultures, and the shared culture between the two, which is constantly changing and open to outside contributions. ${ }^{122}$ Keith Banting and Stuart Soroka, skeptics of interculturalism, define it as an approach that positions the Francophone majority culture as the central hub towards which other minority cultures are expected to converge. However, they also define it as a balancing act to both maintain a connection to Quebec's French culture and history, and to respect the rights and practices of immigrants and minorities. ${ }^{123}$ It should also be noted that, while much of the literature refers to immigrants in Quebec as a whole, the vast majority of these immigrants live in Montreal. While Montreal's metropolitan area represents nearly half of Quebec's total population, visible minorities constitute 16 percent of Montreal's population, compared to constituting 1.6 percent of the rest of Quebec's population combined. ${ }^{124}$

\footnotetext{
122 Bouchard, Interculturalism, 32-33.

123 Banting and Soroka, "Minority Nationalism," 161.

${ }^{124}$ Malenfant, Lebel and Martel, Projections of the Diversity of the Canadian Population, 41.
} 
Perhaps the most dominant supporter of an interculturalism policy, and the most cited, is Gérard Bouchard. His final Commission report, along with Charles Taylor, concluded that the people of Quebec, both politicians and everyday citizens, were overwhelmingly in favour of interculturalism over multiculturalism and assimilation, and emphasized the importance of integration on the basis of the fundamental values of Quebec society. ${ }^{125}$ His most recent work, Interculturalism: A View from Quebec, expands on this report and some of his earlier work, arguing that interculturalism is better equipped to manage Quebec's, as well as Canada's, growing diversity. Bouchard embraces interculturalism, and certainly rejects multiculturalism, which he considers to be a vision introduced by Prime Minister Pierre Trudeau that undermined the idea of two nations within one (Anglophone and Francophone), imposed by English-speaking Canada on French-speaking Quebec. Bouchard believes that multiculturalism has devalued Quebec's Francophone history by failing to distinguish it from the many other ethnic groups at the federal level. ${ }^{126}$ Bouchard compares the experiences of Quebec's Francophone population to that of the First Nations, in terms of being a founding nation and often struggling with the majority-minority relationship with the rest of Canada. ${ }^{127}$

In addition, Bouchard proposes the idea of 'inclusive secularism', which he believes cannot exist without interculturalism, and vice-versa. This idea is grounded in the separation of church and state, as well as the equality of religions, the neutrality of the state with regard to all religions, and the preservation of the heritage of all citizens. ${ }^{128} \mathrm{He}$ argues against the wearing of

\footnotetext{
125 Bouchard, Interculturalism, 4.

126 Ibid., 60.

${ }^{127}$ Ibid., 22.

${ }^{128}$ Ibid., 117.
} 
religious symbols by government employees to preserve the neutrality of the state in all matters religious, although he does not support the proposed ban on several symbols, including the wearing of a hijab or face covering, which was the controversy that precipitated the establishment of the Commission for Reasonable Accommodation in 2007. Therefore, Bouchard's proposition is not made fully clear even though he does declare the need for an official definition of a process to deal with cases like this. ${ }^{129}$ Overall, Bouchard's work proves pivotal as a detailed and comprehensive view of interculturalism, particularly as the co-author of the Bouchard-Taylor Report. However, he neglects to analyze the potential and real negative effects of this policy on those it is meant to integrate, with little mention of how interculturalism could benefit the economic integration of immigrants, which is arguably as important as the social aspect.

In a European context, an important scholarly debate on the multiculturalism versus interculturalism issue, known as the Cantle-Modood debate, was led by Ted Cantle and Tariq Modood. These authors' discussions of the two integration policies are closely aligned with many of the arguments put forth by scholars in Canada. Cantle argues on the premise that multiculturalism is not fit to govern societies, as it assumes culture is temporally and spatially fixed, while the world has long pointed to complex and multiple patterns of cultural formations. ${ }^{130}$ Meanwhile, Modood defends multiculturalism as a policy that protects minority culture, while admitting that it can be improved upon with elements of interculturalism, such as

129 Bouchard, Interculturalism, 137.

${ }^{130}$ Marco Antonsich, "Interculturalism Versus Multiculturalism - The Cantle-Modood Debate," Ethnicities 16 no. 3 (2015): 470 . 
promoting inter-group contact and cohesion rather than merely multicultural coexistence. ${ }^{131}$ While addressing Quebec specifically many times throughout the debate, Cantle does not mention the consequences of interculturalism on racialized minorities, nor does Modood discuss the consequence of multiculturalism on Quebec's nation-building process.

Overall, there is a very limited analysis of the effects of interculturalism on minorities among the policy's supporters, which tends to focus on the needs of the Francophone majority, and the preservation of the Quebec culture and language. In this respect, Quebec interculturalism is quite utilitarian, as the accommodation of the majority may come at the expense of the minority. Critics of the policy tend to focus on this caveat of the potential detriment to the minority by catering to the majority, regardless of the minority status of Quebecers in Canada more widely. One of the most effective examples of this argument, expressed by Keith Banting and Stuart Soroka, examines the social integration and sense of belonging experienced by racialized minorities in Quebec, compared to the rest of Canada as a whole, and questions whether Quebec's minority nationalism presents barriers to minorities' integration. The authors argue that immigrant integration is more complex in Quebec, as immigrants are presented with competing nation-building agendas by the provincial and federal governments. On the one hand, the Canadian government seeks to bring these immigrants into the pan-Canadian political community, while on the other hand, the Quebec government gives priority to the Quebec nation. ${ }^{132}$

\footnotetext{
${ }^{131}$ Antonsich, "Interculturalism Versus Multiculturalism," 17.

132 Banting and Soroka, "Minority Nationalism," 161.
} 
Newcomers are often caught between these two identity-making processes, which act as barriers to actual inclusion and integration, which in turn impacts their willingness and ability to participate in Quebec society. Banting and Soroka find that the two competing processes contribute to an overall decline in the sense of belonging experienced by racialized minority immigrants, and especially for second-generation immigrants, while white immigrants' sense of belonging tends to remain higher and more static across generations. The economic integration of racialized immigrants is also weaker in Quebec than the rest of Canada, and combined with a weaker sense of belonging, has resulted in these communities feeling less engaged at both the provincial and federal level. ${ }^{133}$ While revealing in itself, this argument would benefit from an additional examination of ethnic Quebecers' sense of belonging to the province, as an inclusion of this perspective could add to the discussion on the limits of Quebec's interculturalism policy not just for immigrants, but for those born in Canada as well.

Michelle Labelle and François Rocher similarly argue that Quebec's policy of interculturalism does not reproduce a sense of belonging among its minority groups, mainly because of language barriers and political tensions. The authors are referring to the recent debate on reasonable accommodation in the workplace and public institutions, on the extent to which minority and immigrant cultural practices should be accommodated, further alienating already marginalized groups. ${ }^{134}$ Labelle and Rocher assert that the barriers these minority communities face present major obstacles to promoting a sense of belonging. Furthermore, the existing policies and discourse used to describe and protect ethnocultural diversity only works to further

\footnotetext{
133 Banting and Soroka, "Minority Nationalism," 170.

${ }^{134}$ Michelle Labelle and François Rocher, "Immigration, Integration and Citizenship Policies in Canada and Quebec: Tug of War Between Competing Societal Projects", in Immigration and Self-government of Minority Nations, ed. Ricard Zapata-Barrero, Diversitas vol.3 (2009): 76.
} 
segment public space into particular administrative categories. According to the authors, the categorization of minorities under specific group headings such as 'cultural communities' and 'visible minorities', has had the unintended and adverse effect of segregating and separating society, deepening ethnic and cultural divides, and working against an inclusive vision for Quebec. ${ }^{135}$ However, the authors do not suggest an alternative to this categorization, or how to address the growing divides between populations without distinguishing between the populations themselves.

Tensions between these two groups, visible minority and non-visible minority, have heightened in the last decade, or at least has been made more popular by media, particularly after the debate on reasonable accommodation.

\section{What is Reasonable Accommodation? The Bouchard-Taylor Report}

The concept of the 'moral contract' as a principle of interculturalism includes the idea of accommodation. That is, balancing the duty to accommodate minorities with the duty of all citizens to adjust their attitudes in an attempt to better understand one another, to close the social gaps between the many groups living within Quebec. ${ }^{136}$ Legally, the accommodations process is meant to rectify situations of indirect discrimination, in which policies or practices may have unintentional and adverse effects based on the grounds for discrimination prohibited by the Charter (race, gender, religion, etc.), or systemic discrimination. In Quebec's Charter of Rights and Freedoms, there are thirteen specific grounds for discrimination that are prohibited, and

\footnotetext{
135 Labelle and Rocher, "Immigration", 77.

${ }^{136}$ Bouchard, Interculturalism, 31.
} 
Chapters 15 through 19 detail the legal grounds for accommodations requests, such as public transportation, public places and hiring or termination of employment. ${ }^{137}$

Legal protection against discrimination is therefore enshrined in the Quebec Charter, and there have been many accommodation cases over the past three decades. The beginning of the perceived "accommodation crisis" was a case concerning religious holidays in 1985, when Theresa O’Malley, a Seventh-day Adventist, along with the Ontario Human Rights Commission won their case against her former employer, Simpsons-Sears. The Supreme Court of Canada handed down its decision that O'Malley should not have been fired by her employer because she refused to work Friday evening and Saturday morning to observe the Sabbath. ${ }^{138}$ Since then, many requests for accommodation have grown in both scope and media attention. A series of incidents and misunderstandings concerning accommodations were widely reported by Francophone media and led to the perception that there was a crisis, particularly following the events of September 11 2001, combined with the spotlight on accommodations process over the wearing of the kirpan in schools, the so-called "tempest in the teapot of the accommodations problem". ${ }^{139}$ Succeeding incidents included a young girl's right to wear her hijab while playing soccer, requests for prayer spaces in certain public facilities, the separation of men and women in some public swimming pools, the removal of the Christmas tree in Montreal's City Hall, and whether a YMCA neighbouring a Hasidic community should frost its windows where young Hasidic boys could see women exercising in tight clothing. ${ }^{140}$

\footnotetext{
137 Schaffer, “Cosmopolitanizing Cosmopolitanism?” 143.

138 Bouchard and Taylor, "Building the Future," 48.

139 Schaffer, “Cosmopolitanizing Cosmopolitanism?” 143-144.

140 Pierre Anctil, "Introduction," in Religion, Culture, and the State: Reflections on the Bouchard-Taylor Report, ed. by Howard Adelman and Pierre Anctil (Toronto: University of Toronto Press, 2011), 5.
} 
Public sentiment seemed to support limits to requests for accommodations made by minority populations, with many Quebecers believing that immigrants and minorities posed a threat to Quebec's national and cultural identity, as well as “the perceived centrality of gender equality and secularism to its identity". ${ }^{141}$ These beliefs reflect the opinion that ethnic and religious minorities do not respect gender equality, as demonstrated by hostility towards the burqa and niqab, a sentiment echoed in France, which banned niqabs in $2011 .{ }^{142}$ Leading up to the 2007 Quebec provincial election, the Action Démocratique du Québec (ADQ) ran on an antiimmigrant platform, transforming a relatively marginal party into the second strongest in the province, winning more seats than the separatist PQ. ADQ leader Mario Dumont was widely criticized for exploiting the issue of reasonable accommodation for minorities, particularly Muslims, who he claimed were receiving excessive special privileges. ${ }^{143}$ The final straw came in January 2007, when the municipal council of Hérouxville, with a population of 1,300 people passed a code of conduct for future immigrants outlining the do's and don'ts and stating that no special accommodations would be made for ethnic or religious minorities. ${ }^{144}$

Finally, in February of 2007, Premier Jean Charest decided to establish the Consultation Commission on Accommodation Practices Related to Cultural Differences to address the rising controversy concerning the perceived escalation of unreasonable accommodations for minorities by the majority. The Commission was co-chaired by two distinguished intellectuals, historian and sociologist Gérard Bouchard and philosopher Charles Taylor. The former is a long-time

\footnotetext{
${ }^{141}$ Mahrouse, “"Reasonable Accommodation',” 86.

142 Howard Adelman. "Contrasting Commissions on Interculturalism: The Hijab and the Workings of Interculturalism in Quebec and France,” Journal of Intercultural Studies 32, no. 3 (June 2011), 247.

143 Adelman, “Contrasting Commissions," 249.

${ }^{144}$ Anctil, "Introduction," 6.
} 
supporter of the separatist movement, and younger brother of Lucien Bouchard, former Premier of Quebec and leader of the PQ, while the latter is globally recognized for his defence of multiculturalism and is a self-proclaimed federalist. ${ }^{145}$ The Commission's mandate was to:

1. Take stock of accommodation practices in Quebec.

2. Analyze the related issues bearing in mind the experience of other societies.

3. Conduct an extensive consultation on this topic.

4. Formulate recommendations to the government to ensure that accommodation practices conform to Québec's values as a pluralistic, democratic, egalitarian society.146

Over the course of 10 months, the Commission held sessions in 22 regions across the province, received over 900 briefs from individuals and groups, and heard the testimonies of 241 people over 31 days of public hearings, much of which was televised. ${ }^{147}$ Peter Schaffer argues that Bouchard and Taylor's choice to conduct their Report through the citizen route for managing accommodation requests, as opposed to the legal route, closely aligns with the ideals of interculturalism. Schaffer contends that the best way to address issues of indirect and systemic discrimination is through interaction, interpersonal relations, and the mutual education of one another. ${ }^{148}$ While some of the opinions and beliefs expressed in the hearings and public debates did not reflect a successful interculturalist model, by encouraging the participation of the Quebec citizenry in the hearings and public debates, Bouchard and Taylor prioritized many of the ideals

\footnotetext{
${ }^{145}$ Joseph-Yvon Thériault, "Universality and Particularity in the National Question in Quebec," in Rooted Cosmopolitanism: Canada and the World, ed. Will Kymlicka and Kathryn Walker (Vancouver: UBC Press, 2012), 73.

${ }^{146}$ Bouchard and Taylor, Building the Future, 17.

${ }^{147}$ Ibid., 17.

${ }^{148}$ Schaffer, “Cosmopolitanizing Cosmopolitanism?" 146.
} 
of interculturalism, such as the participation of the citizenry in decision-making, equality, and the interaction of ideas.

The Report was released in May 2008, and from the outset, it stated that the claims of an accommodation crisis in Quebec were unsubstantiated, asserting that the perceived threat of excessive accommodation was not a threat to Quebec's language or culture, and that media attention around the "crisis" was wildly disproportionate to the actual cases for accommodation themselves. ${ }^{149}$ By beginning with this observation, the authors set the tone for the rest of the Report, quelling any further claims that the perceived crisis was real and dangerous, and even blamed this rhetoric for turning immigrants into scapegoats. ${ }^{150}$ Overall, the Report makes 37 recommendations regarding the promotion of diversity and integration, including a section specifically devoted to interculturalism. The authors advocate strongly for interculturalism beyond simple discourse, arguing that, to be successful, interculturalist policies must ensure labour market integration and must continue to fight against discrimination on all fronts. Otherwise, interculturalism is an ineffective policy built on empty words. ${ }^{151}$ The Report encourages the Quebec government to enshrine interculturalism in an official statute, contending that a well-defined text would help to articulate and implement the ideas of interculturalism.

Since its release, the Report has generated criticism from both sides of the accommodations debate, one which argues that the Commission did not develop enough recommendations to effectively address Quebec's increasing diversity, and the hostility to this

\footnotetext{
149 Howard Adelman, "Monoculturalism versus Interculturalism in a Multicultural World," in Religion, Culture, and the State: Reflections on the Bouchard-Taylor Report, eds. Howard Adelman and Pierre Anctil (Toronto: University of Toronto Press, 2011), 46.

${ }^{150}$ Bouchard and Taylor, Building the Future, 18.

${ }^{151}$ Ibid., 259.
} 
diversity, while other critics claim that the recommendations called for 'old-stock' Quebecers to accommodate minorities, rather than the other way around. ${ }^{152}$ For the former, the Report implies that issues of discrimination only affect new immigrants, and therefore many of its recommendations address solutions for newcomers. However, critics highlight that the Report does not recognize the barriers faced by immigrants' descendants, or for the visible minorities who were born in Quebec. ${ }^{153}$ Other critics, such as PQ leader Pauline Marois, were disappointed that the Report had not recommended to enshrine Quebec's 'common values', or require that new immigrants demonstrate minimal knowledge of French to become citizens or be eligible to participate in the political sphere. ${ }^{154}$ The authors do not plainly state that the interculturalist model will ease Quebecers' anxieties about the preservation of the French culture, merely stating that those Quebecers resisting the increase in diversity from ethnic minorities will "scarcely have a choice but to get involved, on pain of enormous impoverishment". ${ }^{155}$

The day of its release, Charest immediately dismissed the recommendation to remove the crucifix from the legislative chamber, stating that "we cannot erase history", even though he had previously stated that the separation of church and state is one of the fundamental principles of the Quebec nation. ${ }^{156}$ With this refusal, Charest was implying that secularism should only apply to non-Catholic religious minorities, rather than the religion of Quebec's founders. This immediate dismissal of the Report's recommendation is indicative of the Liberal Party's

\footnotetext{
152 Adelman, "Contrasting Commissions," 249.

${ }^{153}$ Pierre Anctil, "Reasonable Accommodation in the Canadian Legal Context: A Mechanism for Managing Diversity or a Source of Tension?" in Religion, Culture, and the State: Reflections on the Bouchard-Taylor Report, eds. Howard Adelman and Pierre Anctil (Toronto: University of Toronto Press, 2011), 35.

${ }^{154}$ Adelman, "Monoculturalism," 49.

${ }^{155}$ Bouchard and Taylor, Building the Future, 217.

${ }^{156}$ Adelman, "Contrasting Commissions," 250; Banting and Soroka, "Minority Nationalism," 161.
} 
treatment of its other recommendations over the following years. Most of the recommendations were ignored, including the enshrining of interculturalism as an official statute, and others were met with half-measures and stalling techniques to give the appearance that the government was working to quell the discord between the majority and minority. ${ }^{157}$ Today, the recommendations of the Report have been mostly abandoned, and as we will see in the following section, many groups of minorities in the province fare worse than their Quebecer counterparts, calling into question the effectiveness of informal interculturalism.

\section{The Composition and Outcomes of Immigrants in Toronto and Montreal}

I have selected Toronto and Montreal as sites of research because both CMAs have among the highest immigration rates across Canada. In 2013, Toronto received 75,821 of the total 260,404 immigrants to Canada — 29.1 percent — while Montreal received 42,899 — 16.5 percent. ${ }^{158}$ Montreal, of course, is a necessary site of study, as I would like to examine Quebec's policy of interculturalism, and Montreal is its most populous city. Toronto, on the other hand, is often cited as a prime example of the success of Canada's multiculturalism, as it embodies the harmonious coexistence of dozens of cultures within the CMA. ${ }^{159}$ With a greater emphasis on the composition and outcomes of immigrants and minorities in Quebec, this section will compare the two CMAs in terms of economic, social and political inclusion: all factors that precede successful integration. By examining the characteristics of overall immigration trends in

\footnotetext{
${ }^{157}$ Iacovino, “Contextualizing the Quebec Charter of Values,” 50.

158 Immigration, Refugees and Citizenship Canada, Facts and Figures 2014: Immigration overview: Permanent and Temporary Residents, Research and Evaluation Branch (2015), 32-33.

${ }^{159}$ Kymlicka, Multiculturalism, 10.
} 
the two cities, combined with the economic, social and political outcomes of immigrants and visible minorities, we will have a better understanding of their integration.

All of the data that I used, unless otherwise specified, can be acquired through Statistics Canada, from both the 2006 and 2011 censuses. I prefer to use both data sets because, first, not all of the data I analyzed was available from the most recent National Household Survey (NHS), but also because the NHS is not completely reliable, as the long-form census was voluntary. As a result, many vulnerable populations were underrepresented, including recent immigrants, who may not have spoken the language, or may not have had easy access to a computer to complete the survey. I have also used data compiled from SimplyMap Canada and $<$ odesi $>$ (Ontario Data Documentation, Extraction Service and Infrastructure), which allowed me to compare certain variables between the Toronto and Montreal CMAs. The difficulty lies in obtaining information about immigrant outcomes that are specific to the CMAs of Toronto and Montreal, as much of Statistics Canada's publications on immigration and ethnic diversity examines immigration trends in Canada as a whole. In these cases, I have decided to examine Ontario and Quebec exclusively.

With an emphasis on economic inclusion and outcome, the following data will demonstrate that immigrants in Quebec do not fare nearly as well as native-born Quebecers, nor as well as immigrants in Ontario. Immigrants' social inclusion is a bit more difficult to quantify, as there is no effective unit of measurement to gauge successful social integration, but we will see how factors such as region of birth and visible minority status affect the way these groups engage and participate in society. 


\section{Country of Origin and Visible Minorities}

It is important to understand the composition of the immigrant populations of Toronto and Montreal before we can effectively examine their experiences with the Canadian labour market and civic activities. As we will see, immigrants' country of origin and visible minority status have a significant impact on integration outcomes, and any examination of these outcomes would be incomplete without first discussing the ethnic makeup of the immigrant populations of the two CMAs.

Statistics Canada has published multiple reports on the subject of immigrants' ethnic composition, the most recent entitled Immigration and Ethnocultural Diversity in Canada, published in 2013, examining the two concepts together. Consequently, research concerning immigration is inevitably wound together with issues about race, ethnicity, and country of origin. Past censuses collected information on citizens' country of origin and visible minority status across Canada, and a recent report, Projections of the Diversity of the Canadian Population, has estimated future trends based on current numbers. In 2011, the foreign-born population of Toronto accounted for 46 percent of the CMA's total population, numbering about 2,537,400, while 47 percent identified as belonging to a visible minority group. ${ }^{160}$ By 2031 , it is expected that 78 percent of Toronto residents will be either immigrants or children of immigrants, and the number of visible minorities will more than double, accounting for more than 60 percent of the CMA's population. ${ }^{161}$ Meanwhile, the foreign-born population of Montreal is likely to rise from

\footnotetext{
${ }^{160}$ National Household Survey, 2011, Immigration and Ethnocultural Diversity, 10, 17.

${ }^{161}$ Malenfant, Lebel and Martel, Projections, 2, 31.
} 
its 21 percent in 2006, to 30 percent in 2031, while the percentage of visible minorities is expected to increase from 16 percent to 31 percent, nearly double within the span of 25 years.

Currently, South Asians constitute the largest visible minority group in Toronto, and this trend is expected to continue, as the size of this community is expected to triple by 2031 . Thus, nearly one in four individuals identified as members of visible minorities in Toronto will be South Asian. ${ }^{162}$ Statistics Canada also projects that Blacks will represent the largest percentage of any visible minority group in Quebec by 2013, followed closely by Middle Easterners. While this projected increase in Montreal's Black population would be relatively incremental compared to its number in 2006, the increase in the Middle Eastern population is projected to increase nearly three-fold, from representing just 3 percent of the city's population to 8 percent. Montreal is, and is expected to continue as, the Canadian metropolitan area with the largest Middle Eastern community. Together, these two groups are expected to represent nearly half of Montreal's total visible minority population by $2031 .^{163}$

As for country of origin, India appears to be the birth country of the greatest number of immigrants to Toronto in 2011, with over 272,117 people, followed closely by China, which was the birthplace of 230,847 Toronto residents. In Montreal, Haitian immigrants constitute the largest foreign-born population with 66,947 residents, while the second largest group are Italians, with 57,732 residents. The great majority of Italian immigrants to Montreal are well-established, having lived there for over a decade prior to the census. ${ }^{164}$ This is interesting because, despite the

\footnotetext{
162 Malenfant, Lebel and Martel, Projections, 31.

163 Ibid., 33.

164 Environics Analytics and National Household Survey, 2011, Census Plan 2011: Total Immigrant Population of Place of Birth, Accessed July 21, 2016 from SimplyMaps Database.
} 
large Italian population in Montreal, very little literature concerning immigrant integration and interculturalism has mentioned Italians, or clashes between Quebecers and Italians.

In terms of world area, nearly twice as many Toronto immigrants were born in Asia $(1,334,641$ residents) compared to Europe, which was the second most popular region of birth at 676,506 residents in 2011. For Montreal immigrants, Europe was the most popular region of birth at 260,642 of the CMA's residents, while its Asian and Middle Eastern population stood at 244,404 residents. ${ }^{165}$ It should be noted that, while there were more European immigrants in 2011 than Asian or Middle Eastern, this gap is rapidly closing. To put this in perspective, between 2006 and 2011, the European immigration rate only grew by 2.3 percent, whereas the Asian and Middle Eastern immigration rate grew 12.7 percent, the Haitian immigration rate grew by 24.5 percent, and the African immigration rate grew by 50.1 percent. ${ }^{166}$

The increase of immigrants arriving to Canada from Africa, South America, Central America and the Caribbean, as opposed to immigrants from Asia and Europe, increased the share of immigrants settling in Montreal during the 1999-2010 period, as immigrants from these regions were more likely than other regions to choose Montreal as their intended destination. ${ }^{167}$ Some statisticians suggest that the falling rates of immigration to Toronto, and the gradually increasing rates of immigration to Montreal are a result of changes in source regions. ${ }^{168}$ That is, a larger proportion of immigrants from the regions mentioned above has played an important role

\footnotetext{
165 Environics Analytics and National Household Survey, 2011, Census Plan 2011: Total Immigrant Population of Place of Birth, Accessed July 21, 2016 from SimplyMaps Database.

166 Environics Analytics and National Household Survey, 2011, Census Plan 2011: Total Immigrant Population of Place of Birth, Accessed July 21, 2016 from SimplyMaps Database; Environics Analytics and Adjusted Census Data 2006, Immigration: by Detailed Place of Birth, Accessed July 22, 2016 from SimplyMaps Database.
}

${ }^{167}$ Aneta Bonikowska, Feng Hou, and Garnett Picot, Changes in the Regional Distribution of New Immigrants to Canada, Statistics Canada, Catalogue no. 11F0019M - No. 366 (March 2015), 11.

168 Bonikowska, Hou, and Picot, Changes in the Regional Distribution, 18. 
in these changing rates. If we examine recent immigration (immigration to the Montreal CMA over the five years prior to 2011), we can see that an overwhelming majority of newcomers are arriving from Africa, Asia and the Middle East, constituting nearly 58 percent of all recent immigration to the city. Algeria has become the most popular source country, followed closely by Morocco and Haiti. ${ }^{169}$ Due to Quebec's higher preference for immigrants with knowledge of French, immigrants from former French colonies such as these are prioritized.

\section{$\underline{\text { Language }}$}

Canada at large is a country of linguistic diversity, as the 2011 NHS estimated that more than 200 languages are spoken across the country. Aside from English and French, the Chinese languages were the most reported mother tongues, followed by Tagalog and Spanish. ${ }^{170}$ Within Toronto, the vast majority of residents have knowledge of English and/or French, while about 2.3 percent have knowledge of neither, and about 0.3 percent have knowledge of French only (see Figure 1). Across the province of Quebec, 52 percent of residents have knowledge of French only, while 43 percent can speak both English and French. The reality is slightly different within the Montreal CMA. While a majority of residents speak both English and French — 58 percent — about 12 percent speak English only, and another 3 percent have knowledge of neither language. ${ }^{171}$ This is unsurprising, as the vast majority of immigrants in Quebec live in Montreal, illustrating lower rates of knowledge of the province's official language.

\footnotetext{
169 Environics Analytics and National Household Survey, 2011, Census Plan 2011: Recent Immigrant Population of Place of Birth, Accessed July 22, 2016 from SimplyMaps Database.

170 National Household Survey, Immigration and Ethnocultural Diversity, 18-19.

${ }^{171}$ Statistics Canada, 2011 Census of Population, Statistics Canada Catalogue no. 98-314-XCB2011035 (November 2012).
} 
Figure 1 - Knowledge of Official Languages, 2011

\begin{tabular}{|l|c|c|c|c|}
\hline $\begin{array}{l}\text { Knowledge of } \\
\text { Official Languages }\end{array}$ & Ontario & Toronto & Quebec & Montreal \\
\hline English Only & $86.3 \%$ & $85.8 \%$ & $4.7 \%$ & $11.6 \%$ \\
\hline French Only & $0.3 \%$ & $0.1 \%$ & $51.8 \%$ & $28 \%$ \\
\hline English and French & $11 \%$ & $8.8 \%$ & $42.6 \%$ & $57.6 \%$ \\
\hline $\begin{array}{l}\text { Neither English Nor } \\
\text { French }\end{array}$ & $2.3 \%$ & $5.3 \%$ & $>1 \%$ & $2.6 \%$ \\
\hline
\end{tabular}

Source: Statistics Canada, 2011 Census of Population, Statistics Canada Catalogue no. 98-314-XCB2011035.

It appears as though Quebec's anxieties over the loss of the French language are not completely unfounded. Since 2006, the percentage of residents in Montreal, and Quebec more widely, with knowledge of the French language has fallen, corresponding with a slight increase in residents who can speak English (see Figure 2). Based on demographic estimates for 2016, within this ten year period, the number of Montreal residents who reported speaking French exclusively had fallen by 1.6 percent. ${ }^{172}$ However, this estimate is an improvement from 2011 statistics, which showed that the total number of French-only speakers had fallen by a few thousand residents, even though the total population had increased. Demographic estimates for 2016 show that this population of French speakers has recovered those numbers, but has not grown at the same pace as English speakers. This data clearly demonstrates the falling rates of French speakers in Montreal, which corresponds with projections that expect the number of Allophone immigrants to Canada to nearly double from 2006 to 2031.

\footnotetext{
172 Environics Analytics and National Household Survey, 2011, Census Plan 2011: Knowledge of Official Languages, Accessed July 23, 2016 from SimplyMaps Database; Environics Analytics and Adjusted Census Data 2006, Language: Official Languages, Accessed July 23, 2016 from SimplyMaps Database; Environics Analytics and Demographic Estimates, Official Languages, Accessed July 23, 2016 from SimplyMaps Database.
} 


\section{Figure 2 - Knowledge of Official Languages in the Montreal CMA, 2006-2016}

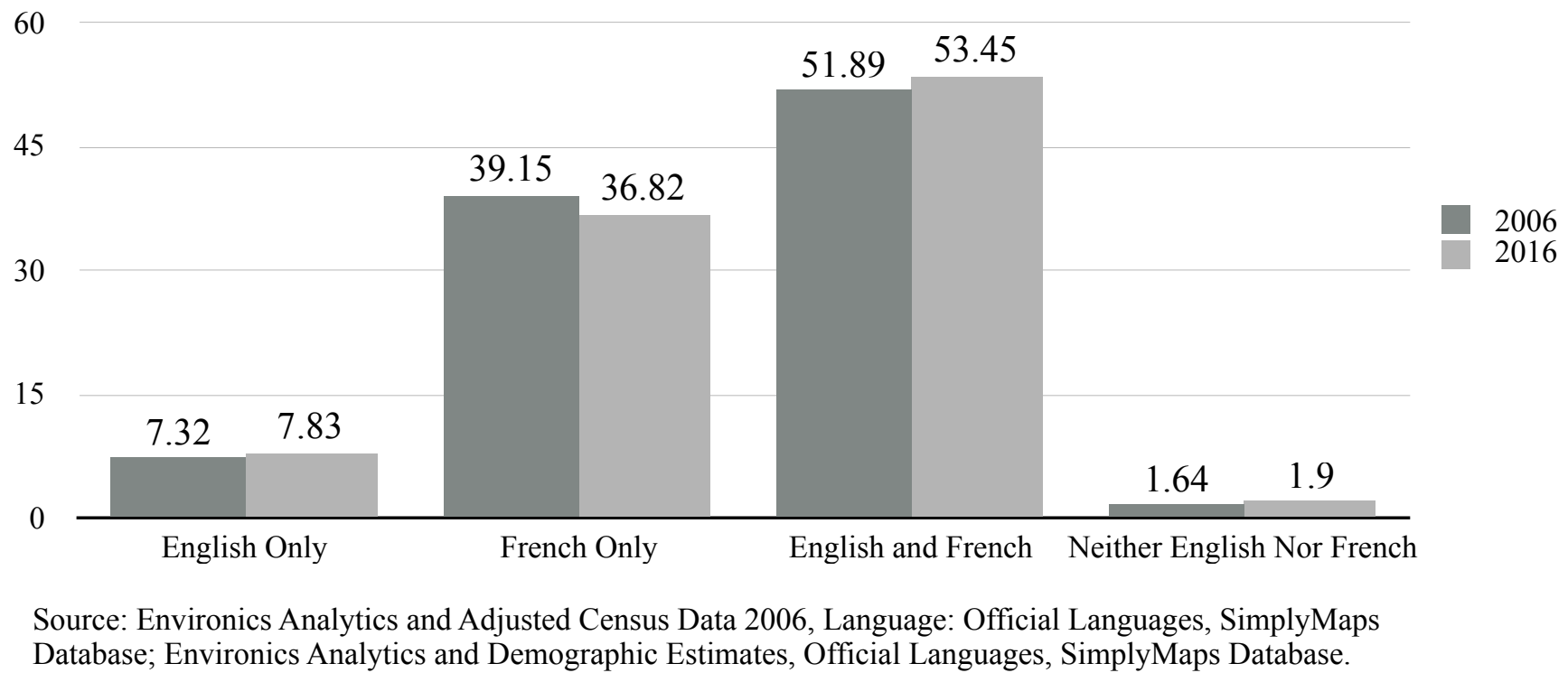

Despite the slight increase in French-speakers to Quebec since 2011, presumably from an increase in French-speaking immigrants, it appears that knowledge of English is slowly encroaching in the city, despite interculturalist efforts to promote 'Francization'. ${ }^{173}$ Bilingualism in Quebec appears to be advancing, but the influence of Bill 101 may be receding.

\section{$\underline{\text { Religion }}$}

The issue of religion has become increasingly politicized over the past decade, both in Quebec and the rest of Canada. In particular, non-Christian religious denominations, which include Judaism, Islam, Buddhism, Hinduism, and Sikhism, have received more criticism than Christian denominations, which includes Catholic, Protestant, Christian Orthodox, and Christian. ${ }^{174}$ Public and legal debates concerning the kirpan in schools, the frosting of windows

\footnotetext{
${ }^{173}$ Iacovino, "Contextualizing the Quebec Charter of Values," 45.

${ }^{174}$ Bouchard and Taylor, Building the Future, 152.
} 
for a Hasidic community, the turban worn by RCMP officers, and a woman's right to wear her niqab during her citizenship ceremony have challenged the limits of accommodation of some religious groups, the majority of which are visible minorities. The federal multiculturalism policy promotes the equality of religious freedoms and practices, as long as those practices are not deemed "barbaric". In 2011, 87 percent of Toronto residents identified as Christian or Catholic, although respondents could identify with multiple religions in the census. The largest nonChristian population was Muslim, accounting for 8 percent of the population, followed by respondents identifying with the Hindu and Jewish faiths, at 6 and 3 percent respectively. ${ }^{175} \mathrm{By}$ 2013, the number of Muslims in Toronto is expected to surpass 1 million based on demographic estimates, doubling in number from low growth estimates, and nearly tripling in number in high growth estimates. ${ }^{176}$

Similarly, Montreal's largest religious population is Catholic, constituting 63 percent of the population, followed by several other Christian denominations. By far, Muslims constitute the largest non-Christian religious group, at about 6 percent, trailed by Judaism at 2 percent. Montreal is projected to experience a significant increase in the number of citizens who identify as belonging to either a non-Christian religious denomination or no religious denomination at all. The number of citizens who identify with a religion other than those under the Christian umbrella is likely to nearly double to 16 percent, while the percentage of those who do identify with a Christian religious denomination is likely to fall from 82 to 70 percent. ${ }^{177}$

\footnotetext{
175 Environics Analytics and National Household Survey, 2011, Census Plan 2011: Religion, Accessed July 25, 2016 from SimplyMaps Database.

${ }^{176}$ Malenfant, Lebel and Martel, Projections, 48.

177 Ibid., 33.
} 
An important element of Quebec's interculturalism is its secularism. Bouchard argues in favour of an 'inclusive secularism', which he defines as the separation of state with matter of religion, while respecting religious differences within the limitations of Quebec's fundamental values, especially equality between men and women. ${ }^{178}$ While this idea of secularism may be idyllic, it does not account for the prejudices held by some in society, which make the "universal respecting of religious differences" difficult. An online poll conducted in 2012 of 1,522 Canadians commissioned by the Association for Canadian Studies and Canadian Race Relations Foundation found that 52 percent of respondents across Canada believed that Muslims cannot be trusted, or can be trusted a little. Among Francophone respondents, this number reached 70 percent, compared to 43 percent among English-speaking Canadians. Thirty-seven percent of respondents believed that immigrants cannot be trusted, or trusted a little; 52 percent among French respondents and 33 percent among English respondents. In comparison, Protestants, the group with the highest levels of trust across all respondents and ages, were evaluated as untrustworthy among 29 percent of respondents. Forty-two percent of respondents believed that discrimination against Muslims was mainly their own fault, while the internet is considered to be the main outlet for spreading racism in Canada. ${ }^{179}$ Although Francophone respondents do not necessarily live in Quebec, the large majority of French-speakers do, as evidenced in the previous section on language.

Islamophobia has become increasingly apparent across Canada, particularly within the last several years, following the rhetoric and viewpoints that emerged out of Hérouxville, the

\footnotetext{
${ }^{178}$ Bouchard, Interculturalism, 134.

${ }^{179}$ Fleras, Racisms in a Multicultural Canada, 104.
} 
Secular Charter Debate, and the recent federal elections. Issues of integration have become conflated with issues about religion, culture and the accommodation of the differences presented by the two. Despite both multiculturalism and interculturalism's support for diversity within reason, visible minorities, including those followers of religions who are easily identified by religious markers, continue to be undervalued, both in Toronto and Montreal. This is apparent as we examine their economic, social and political outcomes.

\section{Economic Outcomes: Employment and Income}

Immigrants and visible minorities' employment and income are important markers of integration, as successful integration in the labour market translates to increased financial and social capital. When individuals are not struggling with poverty, they are more likely to participate in society. ${ }^{180}$ An important measure of employment is the employment rate. Using data from the Labour Force Survey (LFS), we can analyze the employment and unemployment rates across Canada, focusing specifically on immigrants in Toronto and Montreal, while comparing these rates with those of Canadian-born citizens. The LFS focuses on core aged immigrants (24 to 54 years old), as this age group is the most likely to have finished schooling and have not yet retired from the workforce. ${ }^{181}$ This information is available through Statistics Canada, documenting participation in the Canadian labour market from 2006 to 2015 . The LFS uses five types of classifications to study the (un)employment rate in Canada: all landed immigrants, very recent immigrants, recent immigrants, established immigrants, and born in

\footnotetext{
${ }^{180}$ Reitz and Banerjee, "Racial Inequality," 123.

${ }^{181}$ Yssaad, Immigrant Labour Force, 7.
} 
Canada. Very recent immigrants are landed immigrants who have been in Canada for five years or less; recent immigrants are landed immigrants who have been in Canada for five to ten years; and established immigrants are those who have been landed immigrants for over ten years. ${ }^{182}$ This classification system excludes a comprehensive investigation of non-permanent residents in Canada, such as temporary foreign workers, international students and undocumented migrants, all of whom may work in Canada and are similarly affected by changes to the Canadian labour market. However, the LFS accounts for many of these residents in its total population. ${ }^{183}$

While the immigrant employment rate remains lower than the employment rate of Canadian-born in every region across the country, this disparity is most pronounced in Quebec (see Figure 3). In 2015, the employment rate for immigrants, 72.8 percent, was lower than for immigrants in every other province. Similarly, the unemployment rate for immigrants in Quebec, 10.3 percent, was the highest across Canada, and nearly double the rate of 5.7 percent for Canadian-born Quebecers. ${ }^{184}$ Outcomes were similar within the Montreal CMA, with the unemployment rate for both immigrant and Canadian-born slightly higher than the provincial average, 10.6 percent and 6.1 percent respectively (see Figure 3). This disparity is most pronounced for very recent immigrants, whose unemployment rate is nearly three times the rate of Canadian-born, at 16.6 percent.

While immigrants appear to fare better in Toronto, as the unemployment gap between immigrants and Canadian-born is smaller, the two groups have not reached parity. However, it

\footnotetext{
182 Yssaad, Immigrant Labour Force, 9.

183 Statistics Canada, CANSIM Table 282-0102. Labour force survey estimates (LFS), by immigrant status, age group, Canada, regions, provinces and Montreal, Toronto, Vancouver census metropolitan areas, annual, CANSIM. 184 Ibid.
} 
should be noted that the unemployment rate of established immigrants in Toronto is nearly equivalent to the Canadian born rate. Since 2009, the immigrant unemployment rate has fallen continuously from 10.5 percent to 6.3 percent by 2015 , while the Canadian-born rate fell from 6.2 to 5.3 percent. ${ }^{185}$ In Montreal, very recent immigrants fared the worst among all other immigrants, while established immigrants were nearly even with Canadian-born at 5.4 percent.

Figure 3 - Unemployment Rates of Residents in Toronto and Montreal, 2015

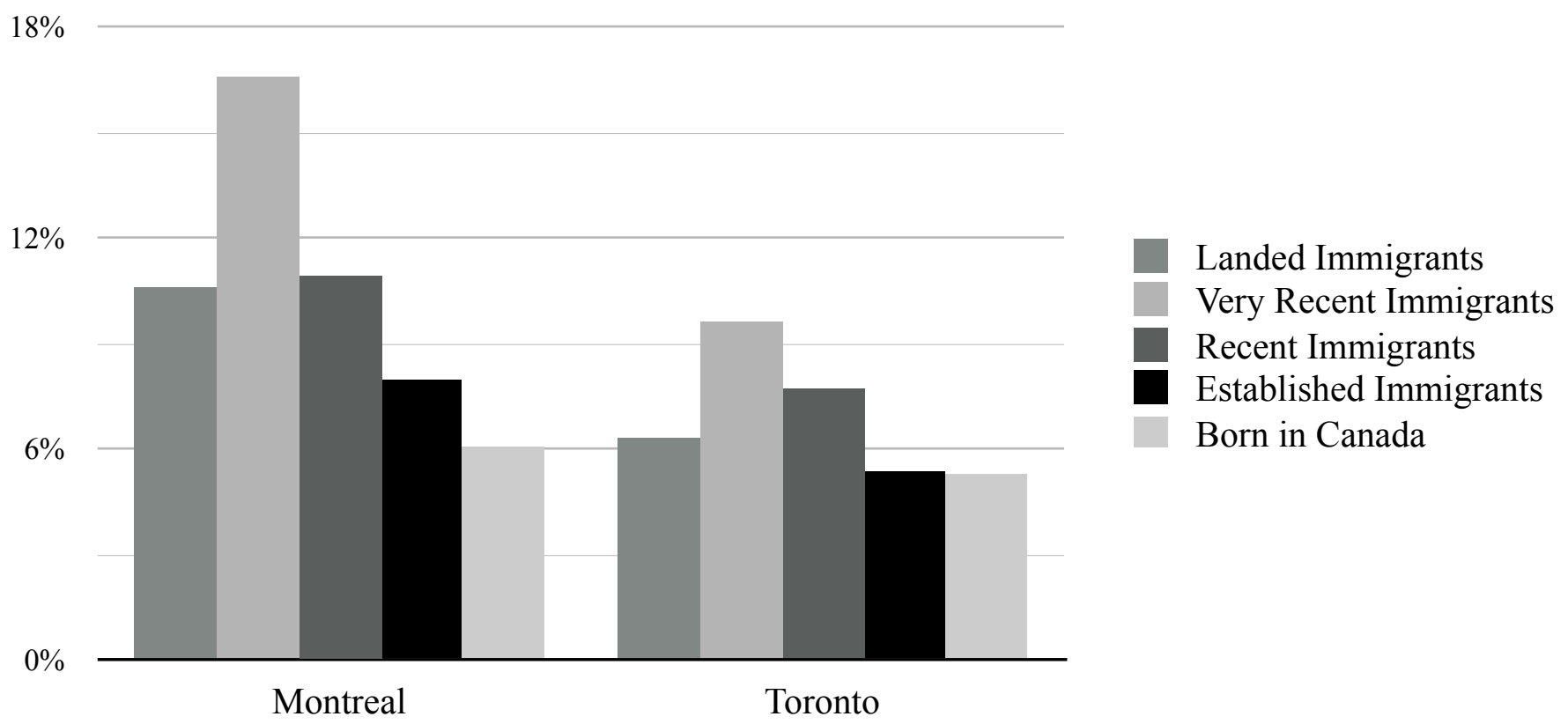

Source: Statistics Canada, CANSIM Table 282-0102.

According to the Longitudinal Immigration Database (IMDB), there is a strong correlation between large immigrant cohort size and higher rates of underemployment, which is characterized by involuntary part-time and precarious work, low-earning jobs, and unemployment. From the year 1982 to 2010, it appears that a 10 percent increase in the size of a cohort of new immigrants correlates with a 0.8 percent decrease of entry earnings (earnings during the first two full years in Canada) among that cohort's men, and a 0.3 percent entry

\footnotetext{
185 Statistics Canada, CANSIM Table 282-0102.
} 
earnings decrease among women. ${ }^{186}$ Immigrants who arrive with little or no Canadian work experience and credentials, and who experience language barriers, are limited to the types of jobs for which many immigrants compete, often low-paying entry jobs. ${ }^{187}$ Consequently, an increase in labour supply from a new larger cohort increases competition for the types of jobs in fields often pursued by newcomers, therefore inadvertently reducing wages for immigrants in that cohort.

\section{Figure 4 - Average Income of Immigrants by World Area, 2013}

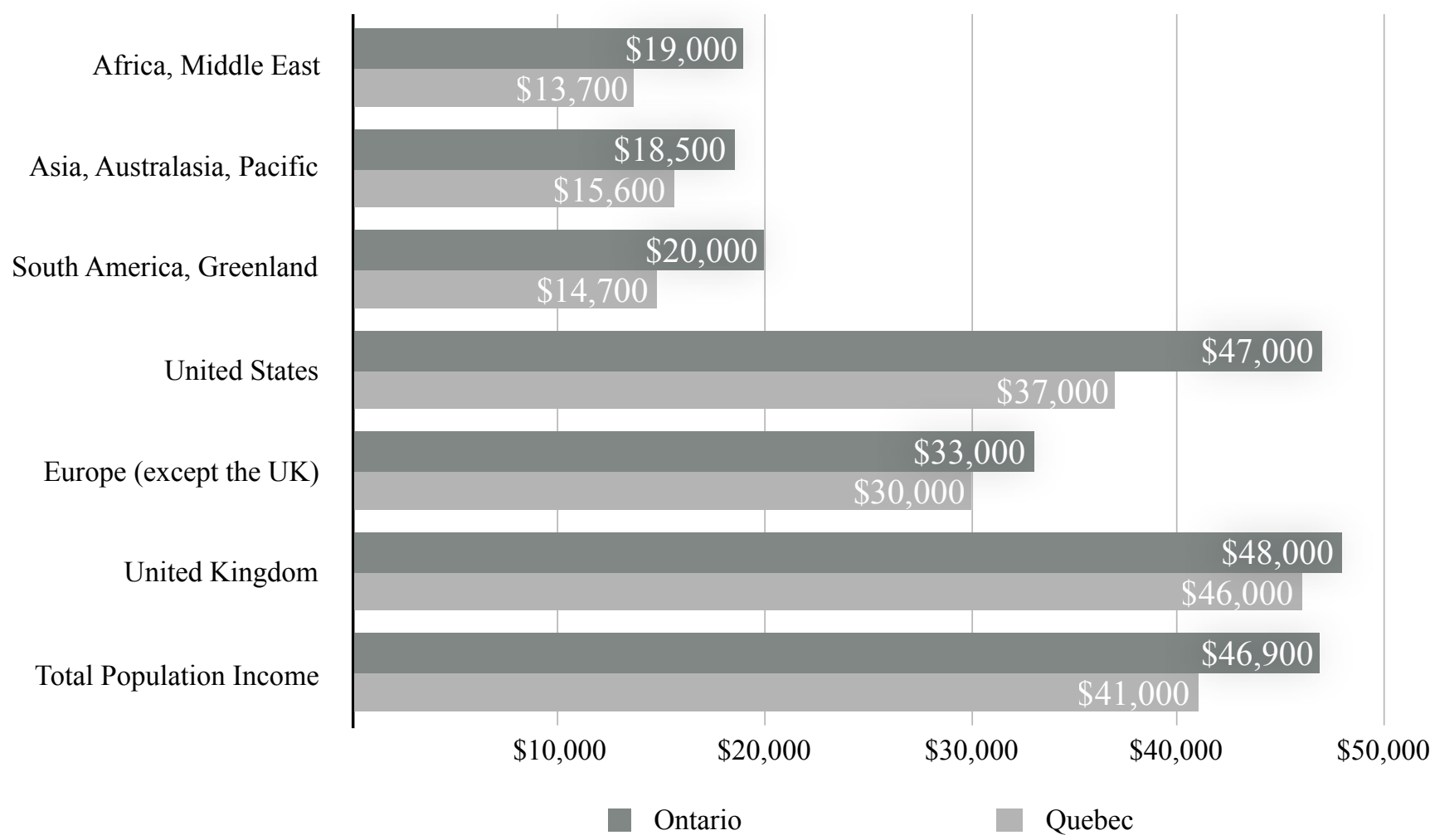

Source: Environics Analytics and Demographic Estimates 2013, Household Income: In Current Year Dollars fromSimplyMaps Database.

Based on data from 2013, it is evident that immigrants did not fare as well as their

Canadian-born counterparts in either province (Figure 4). In Ontario, the group with the lowest

\footnotetext{
${ }^{186}$ Feng Hou, and Garnett Picot, Annual Levels of immigration and Immigrant Entry Earnings in Canada, Statistics Canada, Catalogue no. 11F0019M — No. 356 (February 2014), 5.

${ }^{187}$ Hou and Picot, Annual Levels of immigration, 8-9.
} 
income were immigrants from Asia, Australasia and the Pacific, earning about $\$ 28,400$ less than the average Ontarian, followed closely by immigrants from Africa and the Middle East, who earned an average of $\$ 27,900$ less than the total population. ${ }^{188}$ In contrast, immigrants from the United States and United Kingdom earned the same, if not more, than the average Ontarian, likely due to their proficiency in English and likelihood of Western education and credentials. It is not possible to determine the visible minority status of immigrants from these two groups with the available data.

Immigrants fared far worse in Quebec, with many earning much less than half of the average Quebecer's income. African and Middle Eastern immigrants only earned one third (33.5 percent) of the average Quebec income, and Asian, Australasian and Pacific immigrants earned about 38 percent, or $\$ 25,400$, less than the average. ${ }^{189}$ It is interesting that immigrants from the United Kingdom, an Anglophone country, fared so well comparatively to all other groups, while immigrants from Africa and the Middle East, many of whom come from Francophone countries as we have seen, fare so poorly. Future studies could examine the correlation between income and language to help explain this contradiction and investigate other factors that affect income. Considering the recent increase in immigrants from Africa, the Middle East and South America, racialized immigrants are falling far behind all other groups. From 2004 to 2014, the immigration

\footnotetext{
188 Statistics Canada, CANSIM Table 054-0013, Income of immigrants, by world area, age, immigrant admission category, education qualifications, knowledge of official languages and landing year for Ontario, tax year 2013, annual, CANSIM.

189 Statistics Canada, CANSIM Table 054-0015, Income of immigrants, by world area, age, immigrant admission category, education qualifications, knowledge of official languages and landing year for Quebec, tax year 2013, annual, CANSIM.
} 
rate to Montreal increased by 15.5 percent, which may help to explain their falling wages as larger immigrant cohorts brought down the average. ${ }^{190}$

Another interesting variable through which we can analyze income is religion. As we saw previously, the prevalence of non-Christians is growing across Canada; the number of Sikhs and Buddhists in Canada are expected to double, as the number of Muslims and Hindus are expected to more than triple over the next 25 years. ${ }^{191}$ Meanwhile, the number of Canadians identifying as part of a Christian denomination is expected to grow by two to four thousand people, but these groups expected to fall from 74.8 percent to around 64.8 percent of Canada's total population. ${ }^{192}$ Canadians identifying with Christian denominations are expected to remain the majority and, according to the 2011 census, the non-Christian minority earned a significantly lower income than the Christian majority in both Ontario and Quebec (see Figure 5).

On average, Quebec residents earned 12 percent less than Ontario residents; $\$ 36,000$ annually as opposed to $\$ 40,300 .{ }^{193}$ The income of Christians in Ontario was slightly higher than that of non-Christian residents by about \$3,600, while the difference in Quebec was about $\$ 3,800$. The differences between these two averages is minute, until we consider the effect of the incomes of Jewish residents in each province. The average income of Jewish Canadians was significantly higher than every other religious group surveyed, skewing the averages of nonChristians. The difference in average income between Christians and non-Christians (excluding

\footnotetext{
190 IRCC, Facts and Figures 2014, 32-33.

191 Malenfant, Lebel and Martel, Projections, 25.

192 Ibid., 25.

193 Statistics Canada, National Household Survey, 2011 (99M0001X). Accessed through < odesi>.
} 
Jewish residents) was $\$ 12,000$ in Ontario, and $\$ 9,000$ in Quebec. ${ }^{194}$ Even adjusting for the 12 percent difference in total incomes between the two provinces, it appears as though there is a slightly greater income disparity between Christians and non-Christians (excluding Jewish residents) in Ontario than in Quebec, one of the first instances we have observed in which Ontario minorities fare worse than Quebec minorities compared to the Christian majority. NonChristians still make less than Christians in Quebec, but the disparity is not as great as the relative disparity in Ontario.

Figure 5 - Average Income of Ontario and Quebec Residents by Religion, 2011

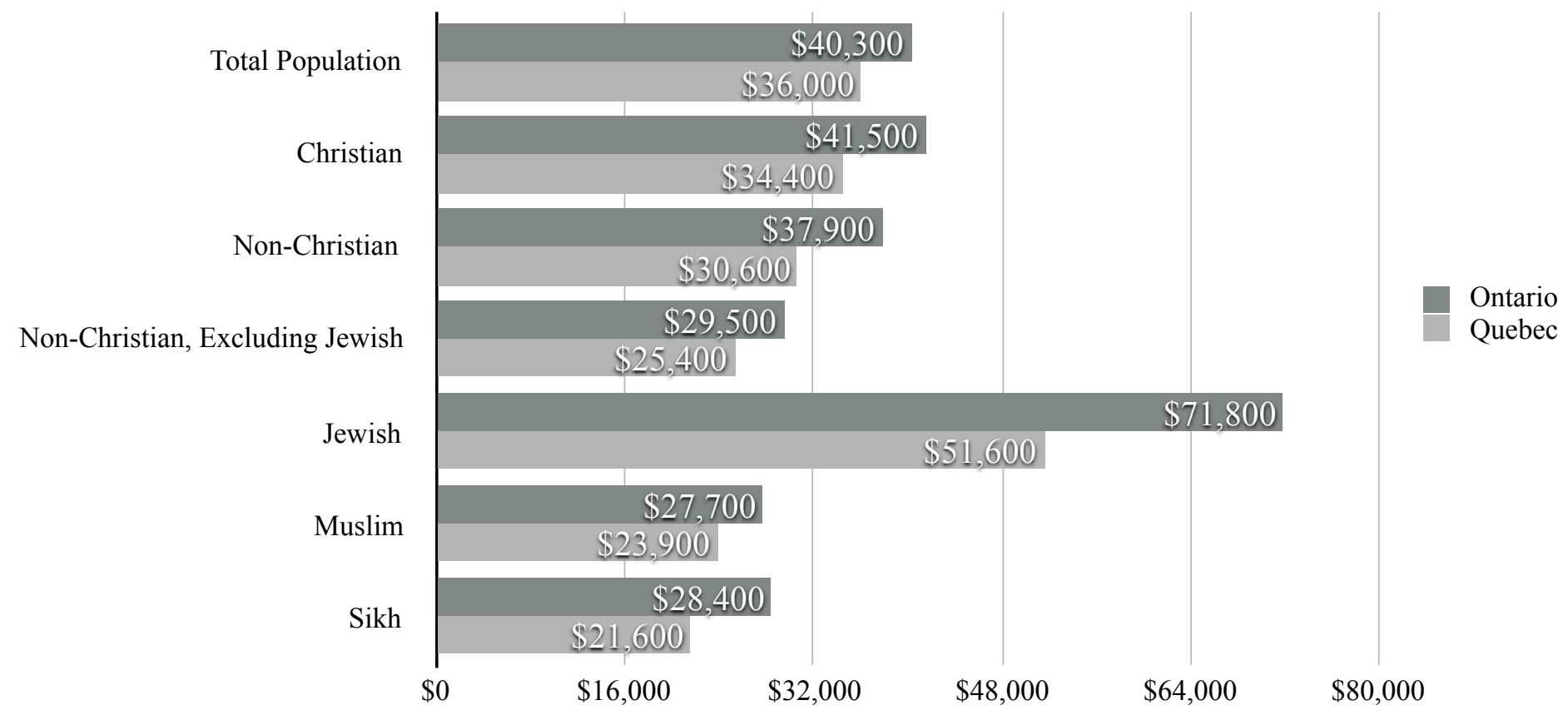

Source: Statistics Canada, National Household Survey, 2011 (99M0001X).

However, if we examine the incomes of Muslims and Sikhs, the two religious groups with the lowest average income in both provinces, those in Quebec fare slightly worse than their Ontarian counterparts, particularly Sikhs, who only number about 9000 across Quebec. ${ }^{195}$

\footnotetext{
${ }^{194}$ Statistics Canada, National Household Survey, 2011 (99M0001X). 195 Ibid.
} 
Perhaps additional research could help to explain this disparity, possibly accounting for the length of the Sikh community's residency in the province, or issues pertaining to discrimination.

An important determinant of immigrant income is education. Potential economic immigrants to Quebec and the rest of Canada are awarded similar points for highest level of education, presumably admitting the most qualified immigrants. However, both the 2006 Census and the 2011 National Household Survey did not collect the required data that would allow us to accurately examine level of education, immigration status, region of birth, and province of residence. For the 2006 Census, the sample size for each of these variables is unreliably small, while the NHS did not collect a detailed record of Canadians' place of birth, listing only Canada, the United States, Europe, Asia and Other Regions. For the purposes of this paper, I am mostly interested in Other Regions. Perhaps the 2016 Census collected this information and can help to fill this gap in knowledge between source region and education.

Fortunately, the 2011 NHS collected data concerning religion and education across all provinces. Regardless of religious affiliation, 23 percent of Ontario residents have a university degree (bachelor's degree and higher), while 45 percent have a high school diploma or less (this includes children who have yet to reach high school). In Quebec, 19 percent of residents have a university degree, and 44 percent have a high school diploma or less. ${ }^{196}$ In both provinces, the Jewish population has the highest proportion of residents with a university degree above bachelor level, 24 percent in Ontario and 19 percent in Quebec, and among the two highest for holders of bachelor's degrees. This helps to explain their relatively high income in both provinces, until we examine the education levels of Muslims, the population with the lowest

\footnotetext{
196 Statistics Canada, National Household Survey, 2011 (99M0001X).
} 
income in Ontario, and second lowest in Quebec. Muslims had the second highest levels of education in Ontario after Jews, as 20 percent have a bachelor's degree and 16 percent have a degree above bachelor level. In Quebec, where the income of Muslims is less than half of the average Jewish income, a larger proportion of Muslims have a bachelor's degree, and have nearly identical rates of postgraduate education (see Figure 6). ${ }^{197}$

Figure 6 - University Education, Religion, and Income, 2011

\begin{tabular}{|c|c|c|c|c|c|c|}
\hline & \multicolumn{3}{|c|}{ Ontario } & \multicolumn{3}{|c|}{ Quebec } \\
\hline & Total & Jewish & Muslim & Total & Jewish & Muslim \\
\hline Average Income & $\$ 40,300$ & $\$ 71,800$ & $\$ 27,700$ & $\$ 36,000$ & $\$ 51,600$ & $\$ 23,900$ \\
\hline $\begin{array}{l}\text { Bachelor's } \\
\text { Degree }\end{array}$ & 14.4 & 25.5 & 20.2 & 12 & 19.6 & 22.2 \\
\hline $\begin{array}{l}\text { Degree Above } \\
\text { Bachelor Level }\end{array}$ & 8.8 & 24.2 & 15.5 & 6.8 & 18.8 & 18.7 \\
\hline
\end{tabular}

Source: Statistics Canada, National Household Survey, 2011 (99M0001X).

While this data demonstrates that Jews and Muslims have similarly high levels of education, but significantly different incomes, it does not help to explain why this inconsistency exists. Does the length of each community's residence in Canada play a role? Were the degrees earned in Canada or abroad? Do the issues of race, language or immigration status impact income? Does Islamophobia have a greater impact on income than anti-Semitism? These questions are compelling, but attempting to answer them would far exceed the scope of this study.

It is evident that immigrants and minorities in both CMAs/provinces are experiencing economic barriers, both in finding a job, and in earning an income on par with the native-born

\footnotetext{
197 Statistics Canada, National Household Survey, 2011 (99M0001X).
} 
majority. The principles of both multiculturalism and interculturalism prohibit discriminatory hiring practices based on race and national or ethnic origin, but it appears that simply prohibiting discrimination does not effectively eliminate it.

\section{Political Outcomes: Voting and Civic Engagement}

The outcomes of immigrants in Toronto and Montreal's political and civic spheres is a bit more difficult to quantify and compare than economic outcomes, as there is very little data available from Statistics Canada on the voting trends and levels of civic engagement of immigrants and minorities in these particular cities. This section will focus on voting trends in Ontario and Quebec, as there is insufficient data available specifically from the two CMA's, drawing from two studies conducted by Canada's General Social Survey (GSS) program in 2013; one which examines social identity, social networks and social engagement in Canada, and another which collected data on the topic of giving, volunteering and participating amongst Canadians. The data I selected was viewed and analyzed through the program $<$ odesi $>$.

Political participation is an important element of integration and belonging in a society, and both multiculturalism and interculturalism encourage newcomers to engage in civic activities. For Marie-Michèle Sauvageau, multiculturalism promotes immigrant participation in the political sphere as a way of protecting civil liberties and the ideals of liberalism.

Interculturalism, on the other hand, deems participation in society is a central issue, and one of the founding pillars of the policy, much in line with Quebec's political history. Under 
interculturalism in Quebec, it is every citizen's responsibility to contribute. ${ }^{198}$ This duty to participation appears to resonate with many immigrants, however, it may not have a similar effect on those born in Canada.

On average, immigrants tend to vote in higher numbers than their Canadian-born counterparts in Ontario, Quebec, and Canada as a whole (see Figure 7). In the 2011 election, the election held previous to the 2013 GSS, 62 percent of Ontario immigrant respondents voted, as opposed to 57 of non-immigrants. In Quebec, the difference is slightly larger, as 56 percent of immigrant respondents voted, while only 46 percent of Canadian-born respondents voted. ${ }^{199}$ While immigrants appear to be more likely to vote in federal elections, those in Ontario seem to be more inclined. The results appear similar for provincial elections as well. In Ontario's 2011 election, 59 percent of immigrant respondents and 52 percent of non-immigrants voted, which implies a lower voter turnout in provincial elections over federal. In Quebec's 2012 election, 54 percent of immigrants respondents voted, while 49 percent of non-immigrants did, while implies a relatively stable voter turnout for Quebec's immigrants and a slightly higher turnout for Canadian-born in provincial elections. ${ }^{200}$ Voter turnout falls even more for municipal elections, in which 49 percent of Ontario immigrants and 34 percent of Quebec immigrants voted. ${ }^{201}$

\footnotetext{
${ }_{198}$ Marie-Michèle Sauvageau, "Du «Comment» Participer à «Pourquoi» Participer? Analyse de la Notion de Participation dans le Multiculturalisme Canadien et L'interculturalisme Québécois," Canadian Ethnic Studies Association 43 no.1-2 (2011), 197, 205.

${ }^{199}$ Statistics Canada, 2015, General Social Survey, 2013 (Canada): Cycle 27, Social Identity (Version 2). Accessed through $<$ odesi $>$.

${ }^{200}$ Ibid.

${ }^{201}$ Ibid.
} 
Figure 7 - Voter Turnout in Last Federal, Provincial and Municipal Elections, 2013

\begin{tabular}{|c|c|c|c|c|}
\hline & \multicolumn{2}{|c|}{ Ontario } & \multicolumn{2}{|c|}{ Quebec } \\
\hline & Immigrant & $\begin{array}{l}\text { Non- } \\
\text { immigrant }\end{array}$ & Immigrant & $\begin{array}{l}\text { Non- } \\
\text { immigrant }\end{array}$ \\
\hline $\begin{array}{l}\text { Voted in the last federal } \\
\text { election }\end{array}$ & 61.8 & 56.5 & 55.5 & 46.3 \\
\hline $\begin{array}{l}\text { Voted in the last provincial } \\
\text { election }\end{array}$ & 58.8 & 51.7 & 54.1 & 49.3 \\
\hline $\begin{array}{l}\text { Voted in the last municipal } \\
\text { election }\end{array}$ & 49.3 & 45.3 & 34.3 & 39.3 \\
\hline
\end{tabular}

Source: Statistics Canada, 2015, General Social Survey, 2013 (Canada): Cycle 27, Social Identity (Version 2).

While it would appear that immigrants are more likely to vote than non-immigrants, the region of immigrants' place of birth significantly affects their interest or ability to participate in politics. By far, European immigrants reported as having the highest voter turnout for the 2011 federal election of all other regions, with 72 percent in Ontario and 61 percent in Quebec. Immigrants from the Americas had the second highest voter turnout in Ontario, at 60 percent, while immigrants from Oceania had the lowest, at 43 percent. In contrast, Asian immigrants constituted the second highest voter turnout in Quebec at 54 percent, and African immigrants voted the least, at 41 percent. ${ }^{202}$ Jewish and Italian communities, two minority groups with the longest histories in Quebec, tend to be more politically active than recent arrivals, and almost all office-holders in Montreal over the past fifteen years drawn from minority communities came from one of these two groups. ${ }^{203}$ Not only are these communities more likely to possess the

\footnotetext{
202 Statistics Canada, 2015, General Social Survey, 2013 (Canada): Cycle 27, Social Identity (Version 2).

${ }^{203}$ Carolle Simard, "Political Representation of Minorities in the City of Montreal: Dream or Reality," in Electing a Diverse Canada: The Representation of Immigrants, Minorities, and Women, eds. Caroline Andrew, John Biles, Myer Siemiatycki and Erin Tolley (Vancouver: UBC Press, 2008), 88.
} 
financial resources that more recent newcomers lack, but they are also more likely to possess a greater understanding of the electorate system due to their longer residence in the country. ${ }^{204}$ Similarly, one's religion appears to be a critical factor affecting voting habits. Of the seven major religious denominations identified by the 2013 GSS (Buddhism, Christianity, Hinduism, Judaism, Islam, other and no religion), the voter turnout in both provinces vary. While in Ontario, Jewish, Christian and Buddhist respondents had the highest voter turnout, Quebec's "Other", Hindu and Christian voters responded that they had voted in the 2011 election in numbers significantly higher than all other religions. ${ }^{205}$ In both provinces, Muslims exhibited the lowest voter turnout rates - 51 percent in Ontario and 42 percent in Quebec. It is also interesting that Jewish voters turn out in much higher numbers in Ontario, 87 percent, than in Quebec at 62 percent, while 89 percent of Hindus in Quebec voted, as opposed to 52 percent in Ontario. ${ }^{206}$

Another important determinant of voter turnout is visible minority status, which yields similar results in both provinces. Only 54 percent of Ontario's visible minorities reported voting in the 2011 federal election, in comparison to 50 percent in Quebec. ${ }^{207}$ While it is clear that immigrants from both Ontario and Quebec are more likely to vote than non-immigrants, with the exception of Quebec's municipal elections, ethnic and visible minorities are much less likely to participate than immigrants from traditionally European origin and non-visible minorities. In an attempt to explain this divide, some scholars suggest that ethnic communities in Quebec lack

\footnotetext{
204 Simard, "Political Representation," 88.

${ }^{205}$ Statistics Canada, 2015, General Social Survey, 2013 (Canada): Cycle 27, Social Identity (Version 2).

${ }^{206}$ Ibid.

${ }^{207}$ Ibid.
} 
cohesion and homogeneity, which makes it difficult to effectively organize. In turn, ethnic minorities are seriously underrepresented at the municipal and provincial level in Quebec. Those few who are elected from minority groups have been elected in districts or ridings where there is a strong concentration of members of ethnic communities. ${ }^{208}$

In addition to relatively low voter turnout for these groups, ethnic and visible minorities appear to be less likely to both volunteer and donate to a charitable organization than those born in Canada, particularly in Quebec. While immigrants in Ontario do not volunteer as often as nonimmigrants, both groups tend to donate both goods and money at similar rates. In Quebec, nonimmigrants are more likely to participate in volunteering and donating, while immigrants are less likely to participate in both. ${ }^{209}$ Unfortunately, this dataset cannot explain why immigrants, particularly ethnic and visible minorities, are less likely to participate in these civic activities, and perhaps further research could examine this phenomenon.

From the above data, it is evident that immigrants engage with politics and civic activities in different ways than the Canadian-born population in both Ontario and Quebec. Immigrants as a single group are more likely to vote at all three levels of government than non-immigrants, save Quebec's municipal elections, though it appears that those in Ontario appear to vote at a higher rate. In both provinces, European immigrants and non-visible minorities appear to be much more likely to cast a ballot than immigrants from Asia and Africa, most of whom are visible minorities. Of course, there are exceptions, like Hindus' high voter turnout in Quebec and

\footnotetext{
${ }^{208}$ Simard, "Political Representation of Minorities," 85.

${ }^{209}$ Statistics Canada, 2015, General Social Survey, 2013 (Canada): Cycle 27, Giving, Volunteering and Participating. Accessed through $<$ odesi $>$.
} 
African immigrants' high rates of donating in both provinces. ${ }^{210}$ However, it is apparent from the data that immigrants and minorities in Ontario are more likely to engage in civic activities, such as voting, volunteering, and donating, than their counterparts in Quebec. This is surprising, as interculturalism places great importance on citizens' participation in social and political spheres to help shape the future of Quebec, as outlined in the moral contract between immigrants and Quebec society. ${ }^{211}$ More than federal multiculturalism, Quebec's interculturalism emphasizes the idea of reciprocity, that immigrants and minority cultures must make efforts to integrate into the larger political community, an important element of which is learning French. In return, Quebec society will empower these groups by including them in the "common public culture". 212 However, the data does not reflect this importance placed on political participation among Quebec's immigrants, or even among Quebecers born in Canada, suggesting that interculturalism's second pillar, the equal participation and contribution of all citizens, does not play a defining role in the province's political community.

\section{Discussion and Conclusion}

This research was interested in the differences in the economic, social, and political outcomes of immigrants in Toronto and Montreal, and whether these differences could be attributed to the two different immigration integration policies governing the CMAs. More specifically, this research investigated the histories of the official federal policy of multiculturalism and Quebec's informal policy of interculturalism, in an attempt to determine the

\footnotetext{
${ }^{210}$ Statistics Canada, 2015, General Social Survey, 2013 (Canada): Cycle 27, Giving, Volunteering and Participating.

${ }^{211}$ Bouchard, Interculturalism, 32.

${ }^{212}$ Barker, "Learning to be a Majority," 27.
} 
effects of these policies on immigrants and ethnic and religious minorities in Toronto and Montreal. My analysis of immigrants and minorities in Toronto was meant to represent the wider integration experience of these groups across Canada, with the exception of Quebec, as Toronto remains the CMA with the highest share of immigrants in the country. ${ }^{213}$ Meanwhile, Montreal, the Quebec city which hosts the large majority of immigrants in the province, was meant to represent Quebec as a whole. ${ }^{214}$ While Toronto is governed with respect to the official federal policy of multiculturalism, Montreal adheres to Quebec's unofficial policy of interculturalism, and based on the research, the integration experience of immigrants in the two CMAs appears to be comparatively different.

Thus, can the policies of multiculturalism and interculturalism be linked to these differences? Based on the data and research I have gathered, I cannot definitively conclude whether these two policies have a significant or direct impact on the differing economic, social and political outcomes of immigrants in Toronto and Montreal. While it is clear that outcomes between immigrants in the two CMAs and provinces vary, it is unclear whether these differences are a result of multiculturalism and interculturalism, or some other combination of factors affecting immigrant integration.

So what can we deduce about these two policies based on the research? Federal multiculturalism and Quebec interculturalism evolved from different circumstances; Canada as a whole was attempting to manage its growing diversity by setting aside the idea of a Canadian identity and embracing many other cultural identities, while Quebec wanted to preserve its

\footnotetext{
${ }^{213}$ Statistics Canada, Immigration and Ethnocultural Diversity in Canada, 11. ${ }^{214}$ Ibid., 16.
} 
Francophone identity and still make space for its own growing diversity. The findings from both my literature review and analysis of Statistics Canada's data reveal that immigrants and minorities in Montreal and Toronto have experienced integration differently. In both CMAs, these groups fare worse than the Canadian-born population, and ethnic and religious minorities (with the exception of Jews) often fare worse than immigrants from European or Christian backgrounds. Factors such as race, country of origin, language, visible minority status and religion appear to impact the ways in which minorities interact with society, particularly the labour market, as demonstrated by their relatively low income. Integration appears especially difficult for Muslims, who demonstrate the lowest income and civic participation rates, but among the highest university completion rates. And while the outcomes of these groups are similarly low in both CMAs, relative to the Canadian-born population, immigrants and minorities fare significantly worse in Montreal than in Toronto. Even after accounting for the fact that residents in Montreal, and Quebec more widely, earn less annually and participate in civic activities less frequently than in Toronto, Montreal's immigrant and minority population is falling far behind the Canadian-born population.

Interculturalism does not appear to be fostering greater inclusion or a more successful integration experience for immigrants and minorities in Quebec over the rest of Canada; quite the opposite. Quebec's unique cultural and political history precipitated the province's support of interculturalism over multiculturalism, placing a greater priority on the preservation of the French language and the belief that newcomers should accommodate Quebec's culture, rather than the other way around. ${ }^{215}$ The Quebec government has the ability to select its own economic

\footnotetext{
215 Banting and Soroka, "Minority Nationalism,” 161.
} 
immigrants, independent from federal intervention, therefore deeming these immigrants as desirable based on their admission. Yet, it is evident based on their relatively poor economic outcomes that immigrants, particularly minorities, are undervalued and falling behind despite high rates of university completion.

Charles Taylor has argued that the differences between multiculturalism and interculturalism lay less within the policies themselves than within the stories behind each. In other words, he asserts that the 'multi' story sets aside the traditional ethno-historical identity of Canada, filling that void instead with all of society's other cultures, declaring them to be equal. The 'inter' story grows from the historic identity of the Quebec nation, Francophone in nature, and slowly evolves to include the cultures and voices of new citizens who, regardless of identity, are declared equal. ${ }^{216}$ While the idea of equality of all cultures is present in the doctrines of both policies, the difficulty lies in the actual implementation of equality. Neither the federal policy of multiculturalism nor Quebec's informal policy of interculturalism has a clear or well-defined plan of how the policies will achieve the successful integration of immigrants and minorities. This is problematic for Canada, outside of Quebec, as the ideals of multiculturalism have many supporters, and the policy is often cited as one of the country's greatest attributes. ${ }^{217}$ This is also problematic for Quebec, and the Quebec nation-building process, as the provincial government still has not enshrined interculturalism as law or recognized it as its official integration policy despite many recommendations to do so. Without the full support of the Quebec government, the principles of interculturalism are difficult to define and enforce, as suggested by the Bouchard-

\footnotetext{
${ }^{216}$ Taylor, “Interculturalism or Multiculturalism?”, 418.

${ }^{217}$ Kymlicka, "The Current State of Multiculturalism," 7.
} 
Taylor Report. ${ }^{218}$ As the two policies currently exist, they are difficult to enforce and remain more as ideals of managing diversity, rather than commandments. Until the economic, social and political barriers facing immigrants and minorities are addressed by each of the policies, it is likely that immigrants in both Quebec and the rest of Canada will continue to struggle to achieve equality.

It is evident that immigrants face barriers in the labour market and political spheres, based on quantifiable research on income, employment rates and voter turnout. However, the social aspect of integration is more difficult to evaluate, as social connections and feelings of belonging cannot be quantified or compared accurately. Present research mostly focuses on the current or short-term integration experiences of immigrants and minorities, rather than the longterm effects of barriers to integration. A longitudinal study investigating factors which affect immigrants' social integration would help to provide researchers and policy-makers more detailed information about these barriers and how to overcome them. A study of this magnitude could help close the gap between both immigrants in Toronto and Montreal, and immigrants and the Canadian-born population. I think that it is important to acknowledge and understand the barriers faced by these groups in order to move forward to achieve successful integration, and improve the existing policies of multiculturalism and interculturalism.

${ }^{218}$ Bouchard and Taylor, "Building the Future," 257. 


\section{Bibliography}

Adams, Michael. Unlikely Utopia: The Surprising Triumph of Canadian Multiculturalism. Toronto: Penguin Canada, 2008.

Adelman. Howard. "Contrasting Commissions on Interculturalism: The Hijab and the Workings of Interculturalism in Quebec and France." Journal of Intercultural Studies 32, no. 3 (June 2011): 245259.

Adelman, Howard. "Monoculturalism versus Interculturalism in a Multicultural World." In Religion, Culture, and the State: Reflections on the Bouchard-Taylor Report, edited by Howard Adelman and Pierre Anctil. Toronto: University of Toronto Press, 2011.

An Intercultural, Plural and Inclusive Québec. Ministère de l'Immigration, de la Diversité et de l'Inclusion Consultation Paper. 2015.

Andrew-Gee, Eric. "Conservatives Vow to Establish 'Barbaric Cultural Practices'Tip Line." The Globe and Mail, October 2, 2015. Accessed July 7. http://www.theglobeandmail.com/ news/politics/conservatives-vow-to-establish-barbaric-cultural-practices-tip-line/ article26640072/.

"Archived - Zero Tolerance for Barbaric Cultural Practices Act receives Royal Assent". News Release, Government of Canada. http://news.gc.ca/web/article-en.do?nid=989099.

Anctil, Pierre. "Reasonable Accommodation in the Canadian Legal Context: A Mechanism for Managing Diversity or a Source of Tension?" In Religion, Culture, and the State: Reflections on the Bouchard-Taylor Report. Edited by Howard Adelman and Pierre Anctil. Toronto: University of Toronto Press, 2011.

Anctil, Pierre. "Introduction." In Religion, Culture, and the State: Reflections on the BouchardTaylor Report, edited by Howard Adelman and Pierre Anctil. Toronto: University of Toronto Press, 2011.

Andrew, Caroline and David Doloreux. "Economic Development, Social Inclusion and Urban Governance: The Case of the City-Region of Ottawa in Canada." International Journal of Urban and Regional Research 36 no.6 (November 2012): 1288-1305.

Antonsich, Marco. "Interculturalism Versus Multiculturalism - The Cantle-Modood Debate." Ethnicities 16 no. 3 (2015): 470-493.

Banting, Keith and Stuart Soroka. "Minority Nationalism and Immigrant Integration in Canada." Nations and Nationalism 18 no.1 (2012): 156-176. 
Barker, Fiona. "Learning to be a Majority: Negotiating Immigration, Integration and National Membership in Quebec." Political Science 62 no.1 (2010): 11-36.

Beaman, Lori G., ed. Reasonable Accommodation: Managing Religious Diversity. Vancouver: UBC Press, 2012.

Beeby, Dean. "Poll ordered by Harper found strong support for niqab ban at citizenship ceremonies". CBC News, September 24, 2015. Accessed April 9, 2016. http:// www.cbc.ca/news/politics/canada-election-2015-niqab-poll-pco-1.3241895.

Bill 60. Charter affirming the values of State secularism and religious neutrality and of equality between women and men, and providing a framework for accommodation requests. 1st Session. 40th Legislature. 2013. http://www.assnat.qc.ca/en/travaux-parlementaires/ projets-loi/projet-loi-60-40-1.html.

Blad, Cory and Philippe Couton. "The Rise of an Intercultural Nation: Immigration, Diversity and Nationhood in Quebec." Journal of Ethnic and Migration Studies 35, no.4 (April 2009): 645-667.

Blatchford, Andy. "Justin Trudeau in victory speech: 'We beat fear with hope, we beat cynicism with hard work'." National Post, October 20, 2015. Accessed April 9, 2016. http:// news.nationalpost.com/news/canada/canadian-politics/justin-trudeau-in-victory-speechwe-beat-fear-with-hope-we-beat-cynicism-with-hard-work.

Bonikowska, Aneta, Feng Hou, and Garnett Picot. Changes in the Regional Distribution of New Immigrants to Canada. Statistics Canada. Catalogue no. 11F0019M - No. 366. March 2015.

Bouchard, Gérard. Interculturalism: A View from Quebec. Translated by Howard Scott. Toronto: University of Toronto Press, 2015.

Bouchard, Gérard and Charles Taylor. "Building the Future: A Time for Reconciliation". Bibliothèque et Archives Nationales du Québec, 2008.

Caidi, Nadia and Danielle Allard. Social Inclusion of Newcomers to Canada: An Information Problem? CERIS Policy Matters, No. 23, 2005.

Csanady, Ashley. “'Barbaric Cultural Practices' bill to criminalize forced marriage, tackle 'honour killings' passes final vote”. The Globe and Mail, June 17, 2015. Accessed April 9, 2016. http://news.nationalpost.com/news/canada/canadian-politics/barbaric-culturalpractices-bill-to-criminalize-forced-marriage-tackle-honour-killings-set-for-final-vote. 
Day, Richard J.F. Multiculturalism and the History of Canadian Diversity. Toronto University of Toronto Press, 2000.

Dewig, Michael. Canadian Multiculturalism. Background Paper. Ottawa: Library of Parliament, 2013. Publication No. 2009-20-E.

Donnelly, Aileen. "Alan Kurdi's father blames Canada for death of his family as PM suggests he will expedite refugee applications." National Post. September 10, 2015. Accessed April 9, 2016. http://news.nationalpost.com/news/canada/alan-kurdis-father-blames-canadafor-death-of-his-family-as-pm-suggests-he-will-expedite-refugee-applications.

Dupré, Jean-François. "Intercultural Citizenship, Civic Nationalism, and Nation Building in Québec: From Common Public Language to Laïcité." Studies in Ethnicity and Nationalism 12 no. 2 (2012): 227-248.

Ethnic Diversity Survey: Portrait of a Multicultural Society. Statistics Canada, Catalogue no. 89-593-XIE, 2003.

Environics Analytics and Adjusted Census Data 2006. SimplyMaps Database.

Environics Analytics and Demographic Estimates 2016. SimplyMaps Database.

Environics Analytics and National Household Survey, 2011. SimplyMaps Database.

Fleras, Augie. Racisms in a Multicultural Canada: Paradoxes, Politics and Resistance. Waterloo: Wilfred Laurier University Press, 2014.

Forde, Shawn D., Donna S. Lee, Cathy Mills, and Wendy Frisby. "Moving Towards Social Inclusion: Manager and Staff Perspectives on an Award Winning Community Sport and Recreation Programs for Immigrants.” Sport Management Review 18 (2015): 126-138.

Galabuzi, Grace-Edward. "Hegemonies, Continuities, and Discontinuities of Multiculturalism and the Anglo-Franco Conformity Order." In Home and Native Land: Unsettling Multiculturalism in Canada, edited by May Chazan et al. Toronto: Between the Lines, 2011.

Government of Canada. Report of the Royal Commission on Bilingualism and Biculturalism. General Introduction, Book I: The Official Languages (1967). Accessed at: http:// epe.lac-bac.gc.ca/100/200/301/pco-bcp/commissions-ef/dunton1967-1970-ef/ dunton1967-70-vol1-eng/dunton1967-70-vol-part2-eng.pdf.

Hou, Feng, and Garnett Picot. Annual Levels of immigration and Immigrant Entry Earnings in Canada. Statistics Canada. Catalogue no. 11F0019M — No. 356. February 2014. 
Howard, Duncan. "Social Inclusion, Social Capital and Immigration.” Canadian Issues (April 2003).

Hudon, Tamara. "Visible Minority Women." Women in Canada: A Gender Based Statistical Report, Statistics Canada, Catalogue no. 89-503-X. March 2016.

Iacovino, Raffaele. "Contextualizing the Quebec Charter of Values: Belonging Without Citizenship in Quebec.” Canadian Ethnic Studies 47, no.1 (2015): 41-60.

Immigration, Refugees and Citizenship Canada. Facts and Figures 2014: Immigration overview: Permanent and Temporary Residents. Research and Evaluation Branch. 2015.

In the Margins, Part II: Reducing Barriers to Social Inclusion and Social Cohesion. Report of the Standing Senate Committee on Social Affairs, Science and Technology, June 2013.

Kelley, Ninette and Michael Trebilcock. The Making of the Mosaic: A History of Canadian Immigration Policy. Toronto: University of Toronto Press, 2010.

Kymlicka, Will, Transatlantic Council on Migration, and Migration Policy Institute. Multiculturalism: Success, Failure, and the Future. Washington, D.C.: Transatlantic Council on Migration, Migration Policy Institute, 2012.

Labelle, Michelle and François Rocher. "Immigration, Integration and Citizenship Policies in Canada and Quebec: Tug of War Between Competing Societal Projects". In Immigration and Self-Government of Minority Nations, edited by Ricard Zapata-Barrero. Diversitas vol.3 (2009).

Le, Huong, Michael Polonsky, and Rodney Arambewela. "Social Inclusion Through Cultural Engagement Among Ethnic Communities.” Journal of Hospitality Marketing \& Management 24 (2015): 375-400.

Mahrouse, Gada. "'Reasonable Accommodation' in Quebec: The Limits of Participation and Dialogue." Race and Class 52 no.1 (2010): 85-96.

Malenfant, Eric Caron, André Lebel and Laurent Martel. Projections of the Diversity of the Canadian Population, 2006-2031. Statistics Canada. Catalogue no. 91-551-X. March 2010.

Ministère de l'Immigration, de la Diversité et de 1'Inclusion. Portraits régionaux 2004-2013: Caractéristiques des immigrants établis au Québec et dans les régions en 2015. Direction de la Planification, de la Recherche et des Statistiques. June 2015. 
Meer, Nasar and Tariq Modood. "How Does Interculturalism Contrast with Multiculturalism." Journal of Intercultural Studies 33 no.2 (2012): 175-196.

National Household Survey, 2011. Immigration and Ethnocultural Diversity in Canada. Statistics Canada. Catalogue no. 99-010-X2011001. 2013.

Omidvar, Ratna and Ted Richmond. "Immigrant Settlement and Social Inclusion in Canada." In Social Inclusion: Canadian Perspectives, edited by Ted Richmond and Anver Saloojee. Toronto: Laidlaw Foundation, 2005.

Oxoby, Robert. "Understanding Social Inclusion, Social Cohesion, and Social Capital." International Journal of Social Economics 36 no.12 (2009): 1133-1152.

Picot, Garnett. Immigrant and Economic Social Outcomes in Canada: Research and Data Development at Statistics Canada. Statistics Canada. Research Paper, Catalogue no. 11F0019M No. 319. December 2008.

Quebec Charter of Rights and Freedoms. Part 1. 1975.

Reitz, Jeffrey G. and Rupa Banerjee. "Racial Inequality and Social Integration.” In Multiculturalism and Social Cohesion: Potentials and Challenges of Diversity, edited by Jeffrey G. Reitz. London: Springer, 2009.

Rocher, François, Micheline Labelle, Ann-Marie Field, and Jean-Claude Icart. Le concept d'interculturalisme en contexte québécois: Généalogie d'un néologisme. Centre de recherche sur l'immigration, l'ethnicité et la citoyenneté. Rapport présenté à la Commission de consultation sur les pratiques d'accommodement reliées aux différences culturelles. December 2007.

Sauvageau, Marie-Michèle. "Du «Comment» Participer à «Pourquoi» Participer? Analyse de la Notion de Participation dans le Multiculturalisme Canadien et L'interculturalisme Québécois." Canadian Ethnic Studies Association 43, no.1-2 (2011): 197-220.

Satzewich, Vic and Nikolaos Liodakis. "Race" and Ethnicity in Canada: A Critical Introduction. Third Edition. Toronto: Oxford University Press, 2013.

Schaffer, Scott. “Cosmpolitanizing Cosmopolitanism? Cosmopolitan Claims Making, Interculturalism, and the Bouchard-Taylor Report." In Rooted Cosmopolitanism: Canad a and the World, edited by Will Kymlicka and Kathryn Walker. Vancouver: UBC Press, 2012.

Simard, Carolle. "Political Representation of Minorities in the City of Montreal: Dream or Reality." In Electing a Diverse Canada: The Representation of Immigrants, Minorities, 
and Women. Edited by Caroline Andrew, John Biles, Myer Siemiatycki and Erin Tolley. Vancouver: UBC Press, 2008.

Stasiulis, Daiva. "Worrier Nation: Quebec's Value Codes for Immigrants." Politikon 40 no.1 (2013): 183-209.

Statistics Canada. 2011 Census of Population. Statistics Canada Catalogue no. 98-314XCB2011035. November 2012.

Statistics Canada. 2012. GeoSearch. 2011 Census. Statistics Canada Catalogue no. 92-142-XWE.

Statistics Canada, 2015. General Social Survey, 2013 (Canada): Cycle 27, Giving, Volunteering and Participating.

Statistics Canada, 2015. General Social Survey, 2013 (Canada): Cycle 27, Social Identity (Version 2).

Statistics Canada. Table 054-0002 - Income of immigrants, by world area, sex, immigrant admission category, education qualifications, knowledge of official languages, and landing year for tax year 2013, annual, CANSIM. Accessed July 5, 2016.

Statistics Canada. Table 054-0013. Income of immigrants, by world area, sex, immigrant admission category, education qualifications, knowledge of official languages and landing year for Ontario, tax year 2013, annual. CANSIM. Accessed July 11, 2016.

Statistics Canada. Table 054-0015. Income of immigrants, by world area, sex, immigrant admission category, education qualifications, knowledge of official languages and landing year for Quebec, tax year 2013, annual. CANSIM. Accessed July 7, 2016

Statistics Canada. Table 282-0102. Labour force survey estimates (LFS), by immigrant status, age group, Canada, regions, provinces and Montreal, Toronto, Vancouver census metropolitan areas, annual. CANSIM. Accessed July 5, 2016.

Taylor, Charles. "Interculturalism or Multiculturalism?" Philosophy and Social Criticism 38 no. 4-5 (2012): 413-423.

Tharoor, Ishaan. "How a Muslim veil is dominating Canada's election race." The Washington Post, October 5, 2015. Accessed April 9, 2016. https://www.washingtonpost.com/news/ worldviews/wp/2015/10/05/how-a-muslim-veil-is-dominating-canadas-election-race/.

Thériault, Joseph-Yvon. "Universality and Particularity in the National Question in Quebec." In Rooted Cosmopolitanism: Canada and the World, edited by Will Kymlicka and Kathryn Walker. Vancouver: UBC Press, 2012. 
Yalden, Maxwell. "Multiculturalism: An Anniversary Celebration." Canadian Ethnic Studies 43 no.1 (2011): 5-15.

Yssaad, Lahouaria. The Canadian Immigrant Labour Market from 2008 to 2011. The Immigrant Labour Force Analysis Series. Statistics Canada, Labour Statistics Division. Catalogue no. 71-606-X, no. 6. December 2011. 